\title{
Incretin-based Therapies for Type 2 Diabetes-Comparisons Between Glucagon-like Peptide-1 Receptor Agonists and Dipeptidyl Peptidase-4 Inhibitors
}

\author{
Timothy Bailey, MD, FACE, CPI \\ Director, AMCR Institute, InC., Escondido, CA
}

\begin{abstract}
Type 2 diabetes exerts a huge toll on both morbidity and mortality, despite an expanding range of antiglycemic drugs and epidemiological evidence highlighting the benefits of effective glycemic control. Incretin-based agents offer important benefits, including a meal-dependent mode of action that may protect against hypoglycemia, and weight loss-in contrast to other antihyperglycemic drugs that cause weight gain. There are now two glucagon-like peptide-1 (GLP-1) receptor agonists and three dipeptidyl peptidase-4 (DPP-4) inhibitors approved for the management of type 2 diabetes in the US. Clinical trials have established the efficacy of incretin-based agents in controlling fasting and post-prandial blood glucose levels as well as glycosylated hemoglobin $\left(\mathrm{HbA}_{1 \mathrm{c}}\right.$ ), both as monotherapy (including as first-line pharmacological treatment) and in combination with other antihyperglycemic treatments. GLP-1 receptor agonists and DPP-4 inhibitors have different mechanisms of action, which may explain their inconsistent efficacy results in direct comparator trials; for example, liraglutide has better efficacy than sitagliptin. However, GLP-1 receptor agonists can cause transient nausea in some patients. There is also evidence of different effects of individual agents within the same class; for example, liraglutide has shown superior efficacy to exenatide when added to metformin and/or sulfonylurea. Linagliptin is not cleared through renal mechanisms, unlike sitagliptin and saxagliptin. Isolated cases of pancreatitis led to concerns about a putative link with incretin-based therapies. However, the data currently available do not support a mechanistic or epidemiological link, although there does appear to be an increased risk of pancreatitis in people with diabetes that is independent of incretin-based treatment. Ongoing studies aim to extend our longer-term understanding of these agents, and hence, allow us to develop an optimal approach to patient management.
\end{abstract}

\section{Keywords}

Dipeptidyl peptidase-4, exenatide, fasting plasma glucose, glucagon-like peptide-1, incretin, linagliptin, liraglutide, saxagliptin, sitagliptin, type 2 diabetes

Disclosure: Timothy Bailey, MD, FACE, CPI, has received consulting honoraria from Roche, Sanofi-Aventis, and Novo Nordisk; speaking honoraria from Amylin, Novo Nordisk, and Sanofi-Aventis; and research support from Boehringer Ingelheim, Bristol-Myers Squibb, GlaxoSmithKline, Lilly, Merck, Novo Nordisk, Roche, and Sanofi-Aventis.

Acknowledgments: Editorial assistance was provided by Sharon Cato at Touch Briefings and funded by Novo Nordisk.

Received: November 30, 2011 Accepted: December 23, 2011 Citation: US Endocrinology, 2011;7(2):82-94 DOI: 10.17925/USE.2011.07.02.82

Correspondence: Timothy Bailey, MD, FACE, CPI, AMCR Institute, Inc., 700 West El Norte Parkway Suite 201, Escondido, California 92026. E: tbailey@amcrinstitute.com

Support: The publication of this article was funded by Novo Nordisk. The views and opinions expressed are those of the author and not necessarily those of Novo Nordisk.

Type 2 diabetes is a key public health issue, affecting over one in 10 US residents aged 20 years or more. ${ }^{1}$ People with diabetes are twice as likely to die at any age than the non-diabetic population of similar age, although the range of antidiabetic therapies now includes over 10 drug classes. ${ }^{1}$ Despite much progress, diabetes remains the leading cause of blindness, kidney failure and non-traumatic lower limb amputations in the US. ${ }^{1}$ This continuing toll of both mortality and morbidity underscores the need for more effective diabetes management. Large-scale epidemiological studies, such as the United Kingdom prospective diabetes study (UKPDS), have shown clear benefits from tight glycemic control in type 2 diabetes. ${ }^{2}$ This study of 3,867 patients with newly diagnosed type 2 diabetes linked a mean hemoglobin $A_{1 c}$ (glycosylated hemoglobin, $\left.\mathrm{HbA}_{1 \mathrm{C}}\right)$ of $7 \%$ (0.9\% lower than in the control group) with a $12 \%$ risk reduction for any diabetes-related endpoint, a $10 \%$ risk reduction for any diabetes-related death, and a $25 \%$ risk reduction for microvascular endpoints over 10 years. ${ }^{2}$

Used alone, conventional antidiabetic medications, such as sulfonylureas and insulins, do not lead to durable glycemic control. Compared with other antidiabetic agents, insulin is linked with twice as many hypoglycemic episodes, and insulin, sulfonylureas, and thiazolidinediones are linked with increased weight gain. These adverse effects (AES) may lead to poor treatment adherence, thus impairing glycemic control. Newer treatments, such as incretins, offer effective glycemic control without the characteristic side effects of conventional drugs-e.g., weight gain. ${ }^{3,4}$ 
Incretin-based therapies now include two classes: glucagon-like peptide-1 (GLP-1) receptor agonists and dipeptidyl peptidase-4 (DPP-4) inhibitors. However, there are important differences between individual agents, even within these classes. This article will discuss mechanisms of action (MOA), efficacy and safety data, and effects on body weight, highlighting differences and similarities between GLP-1 receptor agonists and DPP-4 inhibitors, and the clinically relevant advantages both classes of incretins may provide compared with more established drugs.

\section{Glucagon-like Peptide-1 Receptor Agonists and Dipeptidyl Peptidase-4 Inhibitors}

All incretin-based therapies approved to date are for glycemic control in addition to diet and exercise for adults with type 2 diabetes, either as monotherapy or in combination with metformin, sulfonylureas, or thiazolidinediones. ${ }^{5-9}$ Sitagliptin and saxagliptin, and exenatide are also approved for use in combination with insulin and insulin glargine, respectively. ${ }^{5,8}$ The US Food and Drug Administration (FDA) approved the first GLP-1 receptor agonist, exenatide, twice daily, in April 2005, and the first commercial DPP-4 inhibitor, sitagliptin, in October 2006. ${ }^{10}$ Two additional DPP-4 inhibitors, saxagliptin and linagliptin, received FDA approval in July 2009 and May 2011, respectively. ${ }^{6,7}$ The FDA approved liraglutide, a once-daily GLP-1 receptor agonist with $97 \%$ homology to native GLP-1, in January 2010.

\section{Mechanisms of Action}

The endogenous incretins, glucose-dependent insulin peptide (GIP) and GLP-1, are released from the gut in response to food intake. Both stimulate insulin secretion and promote beta-cell proliferation. ${ }^{11}$ GLP-1, but not GIP, also inhibits glucagon secretion, gastric emptying, food intake, and weight gain. ${ }^{11}$ Some, but not all, individuals with type 2 diabetes have reduced GLP-1 secretion and a normal response to GLP-1, so increasing GLP-1 activity offers multiple potential benefits. ${ }^{11,12}$ In contrast, GIP secretion is normal in type 2 diabetes, but the response to GIP is blunted. ${ }^{11-13}$

GLP-1 receptor agonists act directly on GLP-1 receptors in pancreatic beta-cells, and deliver more sustained activity than endogenous GLP-1 because they resist breakdown by the enzyme DPP-4 and can be dosed to pharmacological levels. DPP-4 inhibitors slow DPP-4-catalyzed breakdown of both GLP-1 and GIP, and can double endogenous GLP-1 levels. This may explain the higher efficacy and weight loss seen with GLP-1 receptor agonists compared with DPP-4 inhibitors. The importance of increasing GIP levels in the mechanism of DPP-4 inhibitor activity is unclear, as target cells have an impaired response to GIP in type 2 diabetes. ${ }^{12,13}$

Some evidence suggests that these differences between the physiological effects of GLP-1 receptor agonists and DPP-4 inhibitors would predict superior outcomes for the former. Both drug classes act by increasing GLP-1 levels, but GLP-1 receptor agonists allow direct supplementation to pharmacologically active levels, while DPP-4 inhibitors offer less potential to achieve GLP-1 levels far above physiological levels via their mode of action (i.e., reducing degradation of endogenous GLP-1). Sitagliptin can double or triple plasma GLP-1 concentrations following an oral glucose tolerance test. ${ }^{14}$ GLP-1 levels were similar after a $25 \mathrm{mg}$ or $200 \mathrm{mg}$ dose of sitagliptin, suggesting that any dose-response relationship had leveled out below 30 nM. ${ }^{14}$ Plasma concentrations of liraglutide can increase in a dose-dependent manner to around $13,000 \mathrm{pmol} / \mathrm{l}$, with no evidence of a plateau. ${ }^{15}$

DPP-4 inhibitors have an additional effect on GIP, which also stimulates insulin secretion and suppresses glucose. ${ }^{13,14}$ The importance of increasing GIP levels in the mechanism of DPP-4 inhibitor activity is unclear; however, target cells have an impaired response to GIP in type 2 diabetes, and patients show smaller increases in insulin and less suppression of glucose than non-diabetic individuals. ${ }^{12,13}$ Studies have linked GIP with increased glucagon levels, in contrast with GLP-1, which suppresses glucagon. ${ }^{16,17}$ A recent publication revealed that combining GIP with GLP-1 impairs the latter's glucagon-lowering efficacy in patients with type 2 diabetes. ${ }^{18}$

\section{Efficacy in Non-comparative Trials} Dipeptidyl Peptidase-4 Inhibitors

Randomized controlled trials (RCTs) have shown significant but modest improvements in both $\mathrm{HbA}_{1 \mathrm{c}}$ and fasting plasma glucose (FPG) with the three approved DPP-4 inhibitors-sitagliptin, saxagliptin, and linagliptin_from baseline versus placebo or existing drugs (see Table 1). These drugs appear to have little impact on body weight, and are generally well tolerated (see later sections).

\section{Sitagliptin}

An 18-week, placebo-controlled study of sitagliptin monotherapy reported significantly reduced post-prandial peaks from baseline versus placebo following a meal tolerance test (subset $n=150$; total randomized population $n=521$; mean diabetes duration 4.5 years). ${ }^{19}$ Placebo-subtracted changes in three-hour area under the curve (AUC) over 18 weeks were -6.7 and -7.6 mmol/hour $\mathrm{l}^{-1}$ for sitagliptin $100 \mathrm{mg}$ and $200 \mathrm{mg}$ once daily, respectively (both $p \leq 0.001$ ). ${ }^{14}$ Sitagliptin demonstrated non-inferiority to metformin as monotherapy in 1,050 treatment-naive patients over 24 weeks. ${ }^{20}$ Long-term double-blind follow-up studies revealed similar glycemic control for sitagliptin monotherapy and metformin monotherapy for up to two years..$^{21-23}$

Sitagliptin demonstrated additive efficacy when combined with metformin in a study of 1,091 patients with type 2 diabetes (mean diabetes duration 4.5 years), of whom $50 \%$ had received no oral hypoglycemic agent for at least eight weeks before randomization. ${ }^{21}$ This study compared sitagliptin monotherapy, metformin monotherapy, combined sitagliptin/metformin, and placebo over 24 weeks. Combining sitagliptin with metformin seemed more effective than increasing the metformin dose to improve efficacy-including improving $\mathrm{HbA}_{1 \mathrm{c}}$ and both fasting and post-meal glucose levels. ${ }^{21}$ Double-blind extensions of 30 and 54 weeks confirmed the efficacy of this combination for up to two years. ${ }^{22,23}$

A 24-week trial in 701 metformin-treated patients with a mean diabetes duration of 6.2 years also reported significant improvements in post-meal glucose with $100 \mathrm{mg}$ sitagliptin compared with placebo (two-hour AUC, $\mathrm{p}<0.001){ }^{24}$ Sitagliptin showed non-inferiority to glipizide as an adjunct to ongoing metformin treatment in a 52-week study that included 1,172 patients (average known type 2 diabetes disease duration 5.8 years). ${ }^{25}$ At two years' extended follow-up, least squares mean changes in $\mathrm{HbA}_{1 \mathrm{c}}$ were $-0.54 \%$ and $-0.51 \%$ with sitagliptin and glipizide, respectively, per 
Table 1: Clinical Trial Efficacy Data for Marketed Dipeptidyl Peptidase-4 Inhibitors in the Treatment of Type 2 Diabetes

\begin{tabular}{|c|c|c|c|c|c|}
\hline \multirow[t]{2}{*}{ Treatment } & \multirow[t]{2}{*}{ Indication, Administration } & \multicolumn{3}{|c|}{ Effect of Treatment from Baseline versus Placebo on: } & \multirow[t]{2}{*}{ Reference } \\
\hline & & $\mathrm{HbA}_{1 \mathrm{c}}$ & FPG & Body Weight & \\
\hline Sitagliptin & $\begin{array}{l}\text { Sitagliptin versus placebo plus } \\
\text { pioglitazone for } 24 \text { weeks }\end{array}$ & $\begin{array}{l}-0.7 \% \text { versus }-0.54 \% \\
(p<0.001)\end{array}$ & $\begin{array}{l}-17.7 \mathrm{mg} / \mathrm{dl} \text { versus }-11.0 \mathrm{mg} / \mathrm{dl} \\
(p<0.001)\end{array}$ & $+1.8 \mathrm{~kg}$ versus $+1.5 \mathrm{~kg}$ & $\begin{array}{l}\text { Rosenstock } \\
\text { et al., } 2006^{29}\end{array}$ \\
\hline Sitagliptin & $\begin{array}{l}100 \text { or } 200 \text { mg monotherapy } \\
\text { versus placebo for } 18 \text { weeks }\end{array}$ & $\begin{array}{l}-0.48 \% \text { and }-0.36 \% \text { versus } \\
0.12 \% \text { (both } p<0.001 \text { ) }\end{array}$ & $\begin{array}{l}-12.6 \mathrm{mg} / \mathrm{dl}(p<0.001) \text { and } \\
-10.8 \mathrm{mg} / \mathrm{dl}(p<0.01) \\
\text { versus } 7.2 \mathrm{mg} / \mathrm{dl}\end{array}$ & $\begin{array}{l}-0.6 \mathrm{~kg} \text { and }-0.2 \mathrm{~kg} \\
\text { versus }-0.7 \mathrm{~kg}\end{array}$ & Raz et al., $2006^{19}$ \\
\hline Sitagliptin & $\begin{array}{l}100 \text { mg or placebo plus } \\
\text { metformin for } 24 \text { weeks }\end{array}$ & $\begin{array}{l}-0.67 \% \text { versus }-0.02 \% \\
(p<0.001)\end{array}$ & $\begin{array}{l}-16.2 \mathrm{mg} / \mathrm{dl} \text { versus } 9.0 \mathrm{mg} / \mathrm{dl} \\
(p<0.001)\end{array}$ & $\begin{array}{l}\text { Small decreases were } \\
\text { observed }(0.6-0.7 \mathrm{~kg})\end{array}$ & $\begin{array}{l}\text { Charbonnel } \\
\text { et al., } 2006^{24}\end{array}$ \\
\hline Sitagliptin & $\begin{array}{l}\text { Sitagliptin } 100 \text { mg qd } \\
\text { Metformin } 500 \text { mg bid } \\
\text { Metformin 1,000 mg bid } \\
\text { Sitagliptin } 50 \text { mg + } \\
\text { metformin } 500 \text { mg bid } \\
\text { Sitagliptin } 50 \text { mg + metformin } \\
\text { 1,000 mg bid versus placebo }\end{array}$ & $\begin{array}{l}-0.66 \%,-0.82 \%,-1.13 \% \\
-1.40 \%, \text { and }-1.90 \% \\
\text { versus }+0.17 \% \text { (all } p<0.001 \text { ) }\end{array}$ & $\begin{array}{l}-17.5 \mathrm{mg} / \mathrm{dl},-27.3 \mathrm{mg} / \mathrm{dl}, \\
-29.3 \mathrm{mg} / \mathrm{dl},-47.1 \mathrm{mg} / \mathrm{dl}, \text { and } \\
-63.9 \mathrm{mg} / \mathrm{dl} \text { versus }+5.8 \mathrm{mg} / \mathrm{dl} \\
\text { (all } p<0.001 \text { ) }\end{array}$ & $\begin{array}{l}\text { Significant weight loss in all } \\
\text { groups ( } p<0.05 \text { ) except } \\
\text { sitagliptin group, which } \\
\text { showed no change }\end{array}$ & $\begin{array}{l}\text { Goldstein et al. } \\
2007^{21}\end{array}$ \\
\hline Saxagliptin & $\begin{array}{l}2.5 \mathrm{mg}, 5 \mathrm{mg} \text {, or } 10 \mathrm{mg} \\
\text { plus metformin } \\
\text { versus metformin alone } \\
\text { for } 24 \text { weeks }\end{array}$ & $\begin{array}{l}-0.59 \%,-0.69 \% \text {, and }-0.58 \% \\
\text { versus }+0.13 \% \text { (all } p<0.0001 \text { ) }\end{array}$ & $\begin{array}{l}-14.31 \mathrm{mg} / \mathrm{dl},-22.03 \mathrm{mg} / \mathrm{dl} \text {, } \\
\text { and }-20.50 \mathrm{mg} / \mathrm{dl} \\
\text { versus }+1.24 \mathrm{mg} / \mathrm{dl} \\
\text { (all } p<0.0001 \text { ) }\end{array}$ & $\begin{array}{l}\text { Mean changes from baseline } \\
\text { at Week } 24:-1.43 \mathrm{~kg},-0.87 \mathrm{~kg} \text {, } \\
\text { and }-0.53 \mathrm{~kg} \text { versus }-0.92 \mathrm{~kg} \\
\text { for metformin alone }\end{array}$ & DeFronzo, $2009^{83}$ \\
\hline Saxagliptin & $\begin{array}{l}5 \mathrm{mg} \text { or } 10 \mathrm{mg} \text { plus } \\
\text { metformin or saxagliptin } \\
10 \mathrm{mg} \text { alone versus } \\
\text { metformin alone for } 24 \text { weeks }\end{array}$ & $\begin{array}{l}-2.5 \% \text { and }-2.5 \% \text { versus }-1.7 \% \\
\text { and }-2.0 \% \text { (all } p<0.0001 \text { versus } \\
\text { monotherapy) }\end{array}$ & $\begin{array}{l}-60 \mathrm{mg} / \mathrm{dl} \text { and }-62 \mathrm{mg} / \mathrm{dl} \\
\text { versus }-31 \mathrm{mg} / \mathrm{dl} \text { and }-47 \mathrm{mg} / \mathrm{dl} \\
\text { (all } p<0.001 \text { ) }\end{array}$ & $\begin{array}{l}\text { Mean changes from baseline } \\
\text { at Week } 24:-1.8 \mathrm{~kg},-1.4 \mathrm{~kg} \text {, } \\
\text { and }-1.1 \mathrm{~kg} \text { for the saxagliptin } \\
\text { groups versus }-1.6 \mathrm{~kg} \text { for } \\
\text { metformin alone }\end{array}$ & $\begin{array}{l}\text { Jadzinsky et al. } \\
2009^{37}\end{array}$ \\
\hline Saxagliptin & $\begin{array}{l}2.5 \mathrm{mg} \text { or } 5 \mathrm{mg} \text { in combination } \\
\text { with glyburide } 7.5 \mathrm{mg} \\
\text { versus glyburide } 10 \mathrm{mg} \\
\text { alone for } 24 \text { weeks }\end{array}$ & $\begin{array}{l}-0.54 \% \text { and }-0.64 \% \text { versus } \\
+0.08 \% \text { (both } p<0.0001 \text { ) }\end{array}$ & $\begin{array}{l}-7.0 \mathrm{mg} / \mathrm{dl} \text { and }-10.0 \mathrm{mg} / \mathrm{dl} \\
\text { versus }+1.0 \mathrm{mg} / \mathrm{dl}(p=0.0218 \\
\text { and } p=0.002)\end{array}$ & $\begin{array}{l}+0.7 \mathrm{~kg} \text { and }+0.8 \mathrm{~kg} \text { with } \\
\text { saxagliptin versus }+0.3 \mathrm{~kg} \\
\text { with up-titrated glyburide } \\
\text { (both } p<0.05 \text { ) }\end{array}$ & $\begin{array}{l}\text { Chacra et al., } \\
2009^{41}\end{array}$ \\
\hline Saxagliptin & $\begin{array}{l}2.5 \mathrm{mg} \text { or } 5 \mathrm{mg} \text { plus } \\
\text { thiazolidinedione versus } \\
\text { placebo plus thiazolidinedione } \\
\text { for } 24 \text { weeks }\end{array}$ & $\begin{array}{l}-0.66 \% \text { and }-0.94 \% \text { versus } \\
-0.30 \% \text { (both } p<0.001 \text { ) }\end{array}$ & $\begin{array}{l}-14.4 \mathrm{mg} / \mathrm{dl}(p=0.0053) \text { and } \\
-18.0 \mathrm{mg} / \mathrm{dl}(p=0.0005) \text { versus } \\
-3.6 \mathrm{mg} / \mathrm{dl}\end{array}$ & $\begin{array}{l}+1.3 \mathrm{~kg} \text { and }+1.4 \mathrm{~kg} \\
\text { versus }+0.9 \mathrm{~kg}\end{array}$ & $\begin{array}{l}\text { Hollander et al., } \\
2009^{42}\end{array}$ \\
\hline Linagliptin & $\begin{array}{l}2.5 \mathrm{mg}, 5 \mathrm{mg}, 10 \mathrm{mg}, \\
\text { or placebo for } 28 \text { days }\end{array}$ & $\begin{array}{l}-0.31 \%,-0.37 \% \text {, and } \\
-0.28 \% \text { placebo-corrected } \\
\text { mean change }(p<0.025)\end{array}$ & $\begin{array}{l}-19.2 \mathrm{mg} / \mathrm{dl},-21.4 \mathrm{mg} / \mathrm{dl} \text {, and } \\
16.6 \mathrm{mg} / \mathrm{dl} \text { versus } 3.2 \mathrm{mg} / \mathrm{dl} \\
(p<0.025)\end{array}$ & $\begin{array}{l}-0.9 \mathrm{~kg} \text { to }-1.6 \mathrm{~kg} \text { for } \\
\text { treatment groups versus } \\
-1.8 \mathrm{~kg} \text { for placebo }\end{array}$ & $\begin{array}{l}\text { Forst et al., } \\
2011^{84}\end{array}$ \\
\hline
\end{tabular}

Bid = twice daily; DPP-4 = dipeptidyl peptidase-4; FPG = fasting plasma glucose; $H b A_{1 c}=$ glycosylated hemoglobin; qd = once daily.

protocol population $(n=504) .{ }^{26}$ A 30-week RCT in 1,035 patients with type 2 diabetes showed that sitagliptin was non-inferior to glimepiride, and an 18-week study in 273 patients found no difference between sitagliptin and rosiglitazone (both in combination with metformin) with regard to $\mathrm{HbA}_{1 \mathrm{c}}{ }^{27,28}$

Studies have demonstrated the efficacy of sitagliptin in combination with thiazolidinediones. ${ }^{29,30}$ Adding sitagliptin to ongoing pioglitazone treatment reduced $\mathrm{HbA}_{1 \mathrm{c}}$ levels by $0.70 \%$ from baseline compared with placebo (between-treatment difference in least squares mean, $p<0.001$ ) and FPG by $17.64 \mathrm{mg} / \mathrm{dl}(\mathrm{p}<0.001)$ in a 24 -week RCT in 353 patients with established type 2 diabetes (mean diabetes duration 6.1 years). ${ }^{29}$ Sitagliptin/metformin combination also achieved better glycemic control than metformin alone as first-line drug treatment in 520 patients. ${ }^{30} \mathrm{HbA}_{1 \mathrm{C}}$ levels were reduced from baseline by $2.4 \%$ and $1.5 \%$ with the combination therapy and the monotherapy, respectively (treatment difference $-0.9 \%, p<0.001) .{ }^{30}$ FPG and two-hour post-prandial plasma glucose (PPG) also fell significantly more with the sitagliptin/metformin combination than with metformin alone $(-63.0 \mathrm{mg} / \mathrm{dl}$ versus $-39.6 \mathrm{mg} / \mathrm{dl}$ and $-113.4 \mathrm{mg} / \mathrm{dl}$ versus $-68.4 \mathrm{mg} / \mathrm{dl}$, respectively; both $\mathrm{p}<0.001)$. When added to glimepiride alone or glimepiride plus metformin, sitagliptin is linked with improved glycemic control: after 24 weeks, compared with placebo, there was a $0.74 \% \mathrm{HbA}_{1 c}$ reduction with sitagliptin added to glimepiride alone $(p<0.001)$ and a $0.89 \% \mathrm{HbA}_{1 c}$ reduction with sitagliptin added to glimepiride plus metformin. ${ }^{31}$

Evidence also supports the efficacy of sitagliptin as an adjunct to insulin in patients with long-standing type 2 diabetes (mean disease duration 12-13 years). Adding sitagliptin to ongoing insulin treatment in 641 patients with type 2 diabetes significantly reduced $\mathrm{HbA}_{1 \mathrm{c}}$ compared with placebo (-0.6\% versus $0.0 \%, p<0.001$ ) over 24 weeks. FPG and two-hour PPG also fell significantly in sitagliptin-treated patients, with placebo-adjusted mean changes of $-14.4 \mathrm{mg} / \mathrm{dl}$ and $-36.0 \mathrm{mg} / \mathrm{dl}$, respectively $(p<0.001){ }^{32}$

\section{Saxagliptin}

Studies have demonstrated the clear benefits of saxagliptin as monotherapy and in combination with metformin, a sulfonylurea, or a thiazolidinedione. ${ }^{33-40}$ 
A 24-week RCT of saxagliptin monotherapy in 401 antihyperglycemic drug-naive patients revealed significant reductions in $\mathrm{HbA}_{1 \mathrm{C}}$ (placebo-adjusted change: $-0.62 \%$ and $-0.65 \%$ with saxagliptin $2.5 \mathrm{mg}$ and $5.0 \mathrm{mg}$, respectively [both $p<0.0001$ versus placebo]), FPG (placebo-adjusted change: -14.94 and $-9.00 \mathrm{mg} / \mathrm{dl}$ with saxagliptin $2.5 \mathrm{mg}$ and $5.0 \mathrm{mg}$, respectively [ $\mathrm{p}<0.05$ versus placebo]), and two-hour PPG (-38.88 and $-36.90 \mathrm{mg} / \mathrm{dl}$, respectively, with saxagliptin $2.5 \mathrm{mg}$ [significance not tested] and $5.0 \mathrm{mg}\left[\mathrm{p}<0.05\right.$ versus placebo]). ${ }^{40}$

In a study of 743 patients whose type 2 diabetes was inadequately controlled by ongoing metformin treatment (mean diabetes duration 6.5 years), adding saxagliptin to metformin significantly improved $\mathrm{HbA}_{1 \mathrm{c}}$ values, the percentage of patients with $\mathrm{HbA}_{1 \mathrm{c}}$ values $\leq 7.0 \%$, and both fasting and post-prandial glucose levels (all $p<0.0001$ from baseline versus placebo). ${ }^{34}$ A second RCT revealed the efficacy and safety profile of saxagliptin with metformin as a first-line antihyperglycemic regimen for patients with relatively recent diagnoses of type 2 diabetes and inadequate glycemic control ( $n=1,306$, mean disease duration 1.4-2 years). Both fasting and post-prandial glucose parameters fell even more significantly after 24 weeks of combination therapy versus either drug as a single agent (all $p \leq 0.0002$ ). ${ }^{37}$ According to a 52-week study in 858 patients, saxagliptin is non-inferior to glipizide as an adjunct to inadequate metformin treatment, with a between-group difference in $\mathrm{HbA}_{1 \mathrm{c}}$ reduction of $0.06 \%{ }^{35}$

A 76-week study in 1,306 treatment-naive patients with type 2 diabetes has also shown the sustained long-term additive efficacy of saxagliptin with metformin as initial combination therapy for up to 76 weeks. $\mathrm{HbA}_{1 \mathrm{C}}$ fell by $2.31 \%$ and $2.33 \%$ with metformin plus saxagliptin $5 \mathrm{mg}$ or $10 \mathrm{mg}$, respectively, compared with $1.79 \%$ with metformin alone and $1.55 \%$ with saxagliptin $10 \mathrm{mg}$ monotherapy $(p<0.0001$ for combinations versus monotherapies). ${ }^{39}$

In 768 randomized patients, adding saxagliptin to a submaximal dose of glyburide was linked with significantly improved $\mathrm{HbA}_{1 \mathrm{C}}$ and both fasting and post-challenge plasma glucose after 24 weeks, compared with increasing the glyburide dose $(p \leq 0.0218)$. Mean disease duration was 6.8-7.1 years; patients entered the study with inadequate glycemic control on submaximal doses of sulfonylurea. ${ }^{41}$

According to a 24-week RCT in 565 patients with type 2 diabetes, saxagliptin can also significantly reduce $\mathrm{HbA}_{1 \mathrm{c}}$ and fasting or post-prandial glucose levels when added to a thiazolidinedione. Patients had insufficient glycemic control $\left(\mathrm{HbA}_{1 \mathrm{c}} \geq 7.0 \%\right.$ to $\left.\leq 10.0 \%\right)$ with ongoing pioglitazone or rosiglitazone treatment (mean disease duration 5.1-5.3 years). ${ }^{42}$ A 52-week extension to this study reported significant $\mathrm{HbA}_{1 \mathrm{c}}$ reductions from baseline versus placebo with both $2.5 \mathrm{mg}$ and $5.0 \mathrm{mg}$ saxagliptin. Placebo-subtracted changes in $\mathrm{HbA}_{1 \mathrm{c}}$ were $-0.39 \%$ and $-0.89 \%$ with $2.5 \mathrm{mg}$ and $5.0 \mathrm{mg}$ saxagliptin, respectively $(p<0.0019$ and $\mathrm{p}<0.0001)$ in the 360 patients who completed the full 76-week follow-up. ${ }^{36}$

\section{Linagliptin}

A phase III RCT including 503 patients with type 2 diabetes, who were either treatment-naive or had received one oral antihyperglycemic drug, showed the significant benefits of linagliptin monotherapy over 24 weeks. Linagliptin-treated patients experienced placebo-corrected reductions in $\mathrm{HbA}_{1 \mathrm{c}}(0.69 \%), \mathrm{FPG}(23.4 \mathrm{mg} / \mathrm{dl})$, and PPG (57.6 mg/dl) [all $\left.p<0.0001\right] .{ }^{43}$
Treatment differences in $\mathrm{HbA}_{1 \mathrm{c}}, \mathrm{FPG}$, and PPG were similar with linagliptin as an add-on to metformin in a 24-week study of 701 patients with type 2 diabetes. Placebo-corrected changes were $-0.64 \%$, $-21.6 \mathrm{mg} / \mathrm{dl}$, and $-66.6 \mathrm{mg} / \mathrm{dl}$ for $\mathrm{HbA}_{1 \mathrm{c}}, \mathrm{FPG}$, and $\mathrm{PPG}$, respectively (all $\mathrm{p}<0.0001){ }^{44}$ Another study, including 333 patients with inadequate glycemic control with metformin alone, showed similar results after 12 weeks of linagliptin $5 \mathrm{mg}$ or glimepiride treatment $(0.75 \%$ and $0.9 \%$ placebo-corrected $\mathrm{HbA}_{1 \mathrm{c}}$ reductions, respectively [ $\left.\left.<<0.001\right]\right)$. Mean type 2 diabetes disease duration was 6.2-8.2 years. ${ }^{45}$ Neither study reported significant body weight changes in the linagliptin treatment groups. ${ }^{44,45}$ In another study, patients randomized to an initial combination regimen of linagliptin plus pioglitazone had treatment differences of $-0.51 \%$ and $-14.22 \mathrm{mg} / \mathrm{dl}$ in $\mathrm{HbA}_{1 \mathrm{c}}$ and $\mathrm{FPG}$, respectively (both $\left.\mathrm{p}<0.0001\right){ }^{46}$

A 24-week RCT in 1,058 patients whose type 2 diabetes was inadequately controlled with metformin plus sulfonylurea treatment also linked add-on linagliptin with significant improvements in glycemic control. ${ }^{47}$ Placebo-adjusted changes in $\mathrm{HbA}_{1 \mathrm{c}}$ and FPG were $-0.62 \%$ and $-12.6 \mathrm{mg} / \mathrm{dl}$, respectively (both $\mathrm{p}<0.0001){ }^{47}$

\section{Glucagon-like Peptide-1 Receptor Agonists}

Data from non-comparative trials regarding the efficacy of GLP-1 receptor agonists is summarized in Table 2.

\section{Exenatide Twice Daily}

A 24-week RCT revealed significant (and dose-dependent) improvements in $\mathrm{HbA}_{1 \mathrm{c}}$ and daily mean post-prandial glucose peaks in treatment-naive patients with two years' type 2 diabetes disease duration receiving first-line antihyperglycemic exenatide treatment twice daily after failed glycemic control using diet and exercise $\left(\mathrm{HbA}_{1 \mathrm{c}}\right.$ $-0.7 \%$ and $-0.9 \%$ versus $-0.2 \%$ [all $p \leq 0.003$ ]; FPG: $-17.46 \mathrm{mg} / \mathrm{dl}$ and $-18.72 \mathrm{mg} / \mathrm{dl}$ versus $-5.22 \mathrm{mg} / \mathrm{dl}[\mathrm{p} \leq 0.029$ for $5 \mu \mathrm{g}$ and $10 \mu \mathrm{g}$ exenatide twice daily versus placebo, respectively]). ${ }^{48}$

Investigators demonstrated the efficacy of exenatide twice daily as an add-on to existing oral agents in three simultaneous 30-week Phase III studies in the US (total randomized population: 1,447). ${ }^{49-51}$ Patients with poor glycemic control with metformin experienced significant improvements in $\mathrm{HbA}_{1 \mathrm{c}}$ and both fasting and post-prandial glucose levels after 30 weeks of treatment with $5 \mu \mathrm{g}$ or $10 \mu \mathrm{g}$ exenatide twice daily. $\mathrm{HbA}_{1 \mathrm{c}}$ values fell by $0.4 \%$ and $0.78 \%$ with $5 \mu \mathrm{g}$ and $10 \mu \mathrm{g}$ exenatide twice daily, respectively, compared with a $0.08 \%$ increase in the placebo group $\left(\mathrm{p}<0.001\right.$ overall). ${ }^{50}$ Similar $\mathrm{HbA}_{1 \mathrm{c}}$ reductions were seen in sulfonylurea-treated patients receiving $5 \mu \mathrm{g}$ and $10 \mu \mathrm{g}$ exenatide twice daily: $0.46 \%$ and $0.86 \%$, respectively, versus a $0.12 \%$ increase with a sulfonylurea alone ( $p<0.0002$ pairwise comparisons). ${ }^{49}$ The third study also demonstrated consistent $\mathrm{HbA}_{1 \mathrm{C}}$ lowering when exenatide twice daily was added to metformin plus sulfonylurea combination therapy: $0.55 \%$ and $0.77 \%$ decreases were seen with $5 \mu \mathrm{g}$ and $10 \mu \mathrm{g}$ exenatide twice daily, respectively, compared with a $0.23 \%$ increase with placebo $(p<0.001)$. Post-prandial glucose AUC fell significantly more with exenatide twice daily than with placebo $(p<0.01) .^{51}$ Mean diabetes duration ranged from 4.9 to 9.4 years for all three 30-week studies.

In another study, exenatide twice daily was shown to improve both $\mathrm{HbA}_{1 \mathrm{c}}$ and fasting plasma glucose as well as post-prandial glucose values over 
Table 2: Clinical Trial Efficacy Data for Marketed Glucagon-like Peptide-1 Receptor Agonists in the Treatment of Type 2 Diabetes

\begin{tabular}{|c|c|c|c|c|c|}
\hline \multirow[t]{2}{*}{ Treatment } & \multirow{2}{*}{$\begin{array}{l}\text { Dosage, Comparators, } \\
\text { Follow-Up }\end{array}$} & \multicolumn{3}{|c|}{ Change from Baseline in Study Drug and Comparator Groups in: } & \multirow[t]{2}{*}{ Reference } \\
\hline & & $\mathrm{HbA}_{1 \mathrm{c}}$ & FPG & Body Weight & \\
\hline Exenatide bid & $\begin{array}{l}5 \mu \mathrm{g} \text { or } 10 \mu \mathrm{g} \text { monotherapy } \\
\text { versus placebo for } 24 \text { weeks }\end{array}$ & $\begin{array}{l}-0.7 \% \text { and }-0.9 \% \text { versus } \\
-0.2 \% \text { (both } p \leq 0.001 \\
\text { versus placebo) }\end{array}$ & $\begin{array}{l}\text { For fasting serum glucose: } \\
-17.46 \mathrm{mg} / \mathrm{dl} \text { and }-18.72 \mathrm{mg} / \mathrm{dl} \\
\text { versus }-5.22 \mathrm{mg} / \mathrm{dl} \text { (both } \mathrm{p}<0.05 \text { ) }\end{array}$ & $\begin{array}{l}-2.8 \mathrm{~kg} \text { and }-3.1 \mathrm{~kg} \text { versus } \\
-1.4 \mathrm{~kg} \text { (both } p<0.005 \text { ) }\end{array}$ & $\begin{array}{l}\text { Moretto et al., } \\
2008^{48}\end{array}$ \\
\hline Exenatide bid & $\begin{array}{l}5 \mu g \text { or } 5 \mu g \text { for four weeks } \\
\text { followed by } 10 \mu g \text { versus } \\
\text { placebo plus su for } 30 \text { weeks }\end{array}$ & $\begin{array}{l}-0.46 \% \text { and }-0.86 \% \text { versus } \\
+0.12 \%(p \leq 0.002)\end{array}$ & $\begin{array}{l}-5.4 \mathrm{mg} / \mathrm{dl} \text { and }-10.8 \mathrm{mg} / \mathrm{dl} \\
\text { versus }+7.2 \mathrm{mg} / \mathrm{dl}(\mathrm{p}<0.05 \text { for } \\
10 \mu \mathrm{g} \text { exenatide versus placebo) }\end{array}$ & $\begin{array}{l}-0.9 \mathrm{~kg} \text { and }-1.6 \mathrm{~kg} \text { versus } \\
-0.6 \mathrm{~kg} \text { for placebo }(p<0.05 \text { for } \\
10 \mu \mathrm{g} \text { exenatide versus placebo) }\end{array}$ & $\begin{array}{l}\text { Buse et al., } \\
2004^{49}\end{array}$ \\
\hline Exenatide bid & $\begin{array}{l}5 \mu g \text { or } 5 \mu g \text { for four weeks } \\
\text { followed by } 10 \mu g \text { versus } \\
\text { placebo plus metformin for } \\
26 \text { weeks; total } 30 \text { weeks }\end{array}$ & $\begin{array}{l}-0.4 \% \text { and }-0.78 \% \text { versus } \\
+0.08 \%(p<0.002)\end{array}$ & $\begin{array}{l}-7.2 \mathrm{mg} / \mathrm{dl} \text { and }-10.8 \mathrm{mg} / \mathrm{dl} \\
\text { versus }+14.4 \mathrm{mg} / \mathrm{dl} \\
(p<0.005 \text { for both })\end{array}$ & $\begin{array}{l}-1.6 \mathrm{~kg} \text { and }-2.8 \mathrm{~kg} \text { versus } \\
-0.3 \mathrm{~kg}(\mathrm{p}<0.05 \text { and } p \leq 0.001 \\
\text { versus placebo, respectively) }\end{array}$ & $\begin{array}{l}\text { DeFronzo et al., } \\
2005^{50}\end{array}$ \\
\hline Exenatide bid & $\begin{array}{l}5 \mu g \text { or } 5 \mu g \text { for four weeks } \\
\text { followed by } 10 \mu g \text { versus } \\
\text { placebo plus SU and metformin } \\
\text { for } 26 \text { weeks; total } 30 \text { weeks }\end{array}$ & $\begin{array}{l}-0.55 \% \text { and }-0.77 \% \text { versus } \\
+0.23 \%(p<0.001)\end{array}$ & $\begin{array}{l}-10.8 \mathrm{mg} / \mathrm{dl} \text { and }-9.0 \mathrm{mg} / \mathrm{dl} \\
\text { versus +14.4 mg/dl }(p<0.0001)\end{array}$ & $\begin{array}{l}-1.6 \mathrm{~kg} \text { and }-1.6 \mathrm{~kg} \text { versus } \\
-0.9 \mathrm{~kg} \text { ( } \mathrm{p} \leq 0.01 \text { versus placebo, } \\
\text { respectively) }\end{array}$ & $\begin{array}{l}\text { Kendall et al., } \\
2005^{51}\end{array}$ \\
\hline Exenatide bid & $\begin{array}{l}10 \mu g \text { versus placebo, } \\
\text { in combination with TZD } \\
\text { with or without metformin } \\
\text { for } 16 \text { weeks }\end{array}$ & $\begin{array}{l}-0.89 \% \text { versus }+0.09 \% \\
\text { with placebo }(p<0.001)\end{array}$ & $\begin{array}{l}-28.62 \mathrm{mg} / \mathrm{dl} \\
\text { versus }+1.80 \mathrm{mg} / \mathrm{dl} \\
\text { with placebo }(p<0.001)\end{array}$ & $\begin{array}{l}-2.15 \mathrm{~kg} \text { versus }+0.14 \mathrm{~kg} \\
\text { with placebo }(p<0.001)\end{array}$ & $\begin{array}{l}\text { Zinman et al., } \\
2007^{52}\end{array}$ \\
\hline Liraglutide & $\begin{array}{l}1.2 \text { mg or } 1.8 \text { mg } \\
\text { monotherapy versus } \\
\text { glimepiride } 8 \text { mg, } \\
52 \text { weeks double-blind } \\
\text { with } 52 \text {-week extension }\end{array}$ & $\begin{array}{l}-0.84 \% \text { and }-1.14 \% \text { versus } \\
-0.51 \% \text { on glimepiride ( } \mathrm{p}=0.0014 \\
\text { and } \mathrm{p}<0.0001 \text {, respectively) at } \\
52 \text { weeks. Significantly greater } \\
\text { reductions from baseline } \\
\text { at two years for both doses } \\
\text { versus glimepiride, using ITT or } \\
\text { completer analyses. Larger } \mathrm{HbA}_{10} \\
\text { reductions occurred in previously } \\
\text { drug-naive subgroup (-1.4 \% } \\
\text { in two-year completers) compare } \\
\text { with entire trial population }\end{array}$ & $\begin{array}{l}-15.12 \mathrm{mg} / \mathrm{dl} \text { and }-29.16 \mathrm{mg} / \mathrm{dl} \\
\text { versus }-5.22 \mathrm{mg} / \mathrm{dl} \\
\text { at } 52 \text { weeks ( } \mathrm{p}=0.027 \text { and } \\
\mathrm{p}=0.0001 \text { versus glimepiride, } \\
\text { respectively) } \\
\text { d }\end{array}$ & $\begin{array}{l}\text { Significant weight reductions } \\
\text { at } 52 \text { weeks and } 104 \text { weeks: } \\
-2.1 \mathrm{~kg} \text { and }-2.7 \mathrm{~kg} \text { versus } \\
+1.1 \mathrm{~kg} \text { ( } \mathrm{p}<0.0001 \text { for both } \\
\text { doses versus glimepiride after } \\
104 \text { weeks) }\end{array}$ & $\begin{array}{l}\text { LEAD-3, } \\
\text { Garber et al., } \\
2009,{ }^{55} 2011^{56}\end{array}$ \\
\hline Liraglutide & $\begin{array}{l}0.6 \mathrm{mg}, 1.2 \mathrm{mg} \text {, or } 1.8 \mathrm{mg} \\
\text { once daily versus glimepiride } \\
4 \mathrm{mg} \text { or placebo, all in } \\
\text { combination with metformin } \\
\text { for } 26 \text { weeks }\end{array}$ & $\begin{array}{l}-0.7 \%,-1.0 \% \text {, and }-1.0 \% \\
\text { versus }-1.0 \% \text { and }+0.1 \% \\
\text { ( } p<0.0001 \text { for all active } \\
\text { treatments versus placebo) }\end{array}$ & $\begin{array}{l}-19.8 \mathrm{mg} / \mathrm{dl},-28.8 \mathrm{mg} / \mathrm{dl} \text {, and } \\
-30.6 \mathrm{mg} / \mathrm{dl} \text { versus }-23.4 \mathrm{mg} / \mathrm{dl} \\
\text { and }+7.2 \mathrm{mg} / \mathrm{dl} \text { (all } \\
\text { liraglutide doses } \mathrm{p}<0.0001 \\
\text { versus placebo) }\end{array}$ & $\begin{array}{l}-1.8 \mathrm{~kg},-2.6 \mathrm{~kg} \text {, and }-2.8 \mathrm{~kg} \\
\text { versus }+1.0 \mathrm{~kg} \text { and }-1.5 \mathrm{~kg} \\
(p<0.0001 \text { for all liraglutide } \\
\text { doses versus glimepiride; } \\
\mathrm{p} \leq 0.01 \text { for } 1.2 \mathrm{mg} \text { or } 1.8 \mathrm{mg} \\
\text { liraglutide versus placebo) }\end{array}$ & $\begin{array}{l}\text { LEAD-2, } \\
\text { Nauck et al., } \\
2009^{58}\end{array}$ \\
\hline Liraglutide & $\begin{array}{l}0.6 \mathrm{mg}, 1.2 \mathrm{mg} \text {, or } 1.8 \mathrm{mg} \\
\text { versus rosiglitazone } 4 \mathrm{mg} \text { /day } \\
\text { or placebo, all in combination } \\
\text { with glimepiride for } 26 \text { weeks }\end{array}$ & $\begin{array}{l}-0.6 \%,-1.1 \% \text {, and }-1.1 \% \\
\text { versus }-0.4 \% \text { and }+0.2 \% \\
\text { (p<0.0001 for } 1.2 \mathrm{mg} \text { and } \\
1.8 \mathrm{mg} \text { liraglutide versus } \\
\text { both rosiglitazone and } \\
\text { placebo; } 0.6 \mathrm{mg} \text { liraglutide } \\
\text { non-inferior to rosiglitazone) }\end{array}$ & $\begin{array}{l}-12.96 \mathrm{mg} / \mathrm{dl},-28.26 \mathrm{mg} / \mathrm{dl} \text {, } \\
\text { and }-28.62 \mathrm{mg} / \mathrm{dl} \text { versus } \\
-15.84 \mathrm{mg} / \mathrm{dl} \text { and }+18.18 \mathrm{mg} / \mathrm{dl} \\
\text { (all liraglutide doses } \mathrm{p}<0.0001 \\
\text { versus placebo; } 1.2 \mathrm{mg} \text { and } \\
1.8 \mathrm{mg} \text { liraglutide } \mathrm{p}<0.01 \\
\text { versus rosiglitazone) }\end{array}$ & $\begin{array}{l}+0.7 \mathrm{~kg},+0.3 \mathrm{~kg} \text {, and }-0.2 \mathrm{~kg} \\
\text { versus }+2.1 \mathrm{~kg} \text { and }-0.1 \mathrm{~kg} \\
\text { (all liraglutide doses } p<0.0001 \\
\text { versus rosiglitazone) }\end{array}$ & $\begin{array}{l}\text { LEAD-1, } \\
\text { Marre et al., } \\
2009^{57}\end{array}$ \\
\hline Liraglutide & $\begin{array}{l}1.2 \mathrm{mg} \text { or } 1.8 \mathrm{mg} \text { versus } \\
\text { placebo, all in combination } \\
\text { with metformin } 1 \mathrm{~g} \text { and } \\
\text { rosiglitazone } 4 \mathrm{mg} \text { for } 26 \text { weeks }\end{array}$ & $\begin{array}{l}-1.5 \% \text { and }-1.5 \% \text { versus } \\
-0.5 \% \text { on placebo }(p<0.0001)\end{array}$ & $\begin{array}{l}-39.6 \mathrm{mg} / \mathrm{dl} \text { and }-43.2 \mathrm{mg} / \mathrm{dl} \\
\text { versus }-7.2 \mathrm{mg} / \mathrm{dl}(\mathrm{p}<0.0001)\end{array}$ & $\begin{array}{l}-1.0 \mathrm{~kg} \text { and }-2.0 \mathrm{~kg} \text { versus } \\
+0.6 \mathrm{~kg} \text { on placebo }(p<0.0001)\end{array}$ & $\begin{array}{l}\text { LEAD-4, } \\
\text { Zinman et al., } \\
2009^{60}\end{array}$ \\
\hline Liraglutide & $\begin{array}{l}1.8 \text { mg versus insulin glargine } \\
\text { or placebo, all in combination } \\
\text { with metformin and } \\
\text { glimepiride for } 26 \text { weeks }\end{array}$ & $\begin{array}{l}-1.33 \% \text { versus }-1.09 \% \text { and } \\
-0.24 \% \text { on insulin glargine } \\
\text { or placebo, ( } p=0.0015 \text { and } \\
p<0.0001 \text {, respectively) }\end{array}$ & $\begin{array}{l}-27.90 \mathrm{mg} / \mathrm{dl} \text { versus } \\
-32.22 \mathrm{mg} / \mathrm{dl} \text { and } \\
+9.54 \mathrm{mg} / \mathrm{dl} \text { on insulin } \\
\text { glargine or placebo, } \\
\text { respectively ( } p<0.0001 \\
\text { versus placebo) }\end{array}$ & $\begin{array}{l}-1.8 \mathrm{~kg} \text { versus }+1.6 \mathrm{~kg} \text { and } \\
-0.42 \mathrm{~kg} \text { on insulin glargine } \\
\text { and placebo, respectively } \\
(p \leq 0.0001 \text { versus both) }\end{array}$ & $\begin{array}{l}\text { LEAD-5, } \\
\text { Russell-Jones } \\
\text { et al., } 2009^{59}\end{array}$ \\
\hline
\end{tabular}

Bid = twice daily; FPG = fasting plasma glucose; GLP-1 = glucagon-like peptide-1; HbA 1 = glycosylated hemoglobin; ITT = intention-to-treat; LEAD = Liraglutide effect and action in diabetes; $S U=$ sulfonylurea; $T Z D=$ thiazolidinedione. 
16 weeks in the $21 \%$ of patients receiving a thiazolidinedione alone and in the $79 \%$ of patients receiving a thiazolidinedione with metformin (all $\mathrm{p}<0.001$ versus placebo). Mean disease duration was 7.3-8.2 years. ${ }^{52}$

\section{Liraglutide}

The extensive Liraglutide effect and action in diabetes (LEAD) program of six clinical trials, with a total randomized population of 4,456 patients with type 2 diabetes, has established the efficacy, tolerability, and safety of liraglutide as part of various combination regimens with sulfonylureas, metformin, or thiazolidinedione or as a monotherapy (see Table 2 and Figure 1). ${ }^{53-60}$

Liraglutide monotherapy significantly reduced $\mathrm{HbA}_{1 \mathrm{c}}$ compared with glimepiride in 746 patients with inadequate type 2 diabetes control and mean disease duration between 5.2 and 5.6 years (LEAD-3 trial, $\mathrm{p} \leq 0.0014$ for liraglutide $1.2 \mathrm{mg}$ and $1.8 \mathrm{mg}$ versus glimepiride $8 \mathrm{mg}$ ). ${ }^{55,61}$ The superiority of liraglutide monotherapy over glimepiride was sustained until the end of a 52-week open-label extension (two year follow-up). ${ }^{56}$ The monotherapy trial yielded comparable FPG and PPG reductions with liraglutide or glimepiride (both superior to placebo) at 52 weeks, but FPG was lower after two years of liraglutide therapy compared with glimepiride $(p=0.0001$ and $p=0.0015$ for $1.8 \mathrm{mg}$ and 1.2 mg doses, respectively). ${ }^{55,56}$ Liraglutide $1.8 \mathrm{mg}$ was also associated with significantly lower PPG than glimepiride after two years $(p=0.0105) .{ }^{56}$

In the LEAD-2 trial, combining liraglutide with metformin yielded significant $\mathrm{HbA}_{1 \mathrm{c}}$ reductions versus placebo over 24 weeks: $-0.8 \%$ (95\% confidence interval [Cl] -1.0 to -0.6$),-1.1 \%(95 \% \mathrm{Cl}-1.3$ to -0.9$)$, and $-1.1(95 \% \mathrm{Cl}-1.3$ to -0.9$)$ with $0.6 \mathrm{mg}, 1.2 \mathrm{mg}$, and $1.8 \mathrm{mg}$ doses, respectively. Liraglutide was non-inferior to glimepiride as an add-on therapy to metformin. Mean daily PPG values fell by $30.6 \mathrm{mg} / \mathrm{dl}, 41.4 \mathrm{mg} / \mathrm{dl}$, $46.8 \mathrm{mg} / \mathrm{dl}$, and $45.0 \mathrm{mg} / \mathrm{dl}$ with liraglutide $0.6 \mathrm{mg}, 1.2 \mathrm{mg}$, $1.8 \mathrm{mg}$, and glimepiride, respectively, compared with $-10.8 \mathrm{mg} / \mathrm{dl}$ in the placebo group $(p<0.001)$. This study included 1,091 patients with poorly controlled type 2 diabetes; mean disease duration was seven to eight years. ${ }^{58}$

The 26-week LEAD-1 study linked liraglutide $(0.6 \mathrm{mg}, 1.2 \mathrm{mg}$, or $1.8 \mathrm{mg}$ per day) with significant $\mathrm{HbA}_{1 \mathrm{c}}$ and $\mathrm{FPG}$ reductions versus placebo $(p<0.0001)$. Liraglutide $1.2 \mathrm{mg}$ and $1.8 \mathrm{mg}$ also showed significantly greater efficacy than rosiglitazone $\left(p<0.0001\right.$ and $p \leq 0.006$ for $\mathrm{HbA}_{1 \mathrm{c}}$ and FPG, respectively, versus placebo). Mean daily PPG values fell by $45.0 \mathrm{mg} / \mathrm{dl}$ and $48.6 \mathrm{mg} / \mathrm{dl}$ with liraglutide $1.2 \mathrm{mg}$ and $1.8 \mathrm{mg}$, respectively ( $p=0.043$ and $p=0.0022)$ and by $32.4 \mathrm{mg} / \mathrm{dl}$ with liraglutide $0.6 \mathrm{mg}(\mathrm{p}<0.0001)$, versus rosiglitazone. ${ }^{57}$

Liraglutide has also shown efficacy in patients with prolonged disease duration (mean duration nine or more years) whose glycemic control is poor despite combination therapy. ${ }^{59,60}$ The LEAD-4 trial compared liraglutide combined with metformin and rosiglitazone with placebo in 533 patients. $\mathrm{HbA}_{1 \mathrm{c}}, \mathrm{FPG}$, and PPG values all fell significantly from baseline in liraglutide-treated patients over 26 weeks $(p<0.0001$, $p<0.0001$, and $p<0.001$, respectively, versus placebo)..$^{60}$ Mean PPG values decreased by $46.8 \mathrm{mg} / \mathrm{dl}$ and $48.6 \mathrm{mg} / \mathrm{dl}$ with liraglutide $1.2 \mathrm{mg}$ and $1.8 \mathrm{mg}$, respectively, compared with $-14.4 \mathrm{mg} / \mathrm{dl}$ in the placebo group. ${ }^{60}$

Adding liraglutide to combined metformin plus a sulfonylurea significantly improved $\mathrm{HbA}_{1 C}, \mathrm{FPG}$, and PPG versus placebo $(p<0.0001)$ in
Figure 1: Percentage of Participants Treated to $\mathrm{HbA}_{1 \mathrm{c}}$ Targets Lower than $7 \%$ in the LEAD-3 Trial $^{56}$
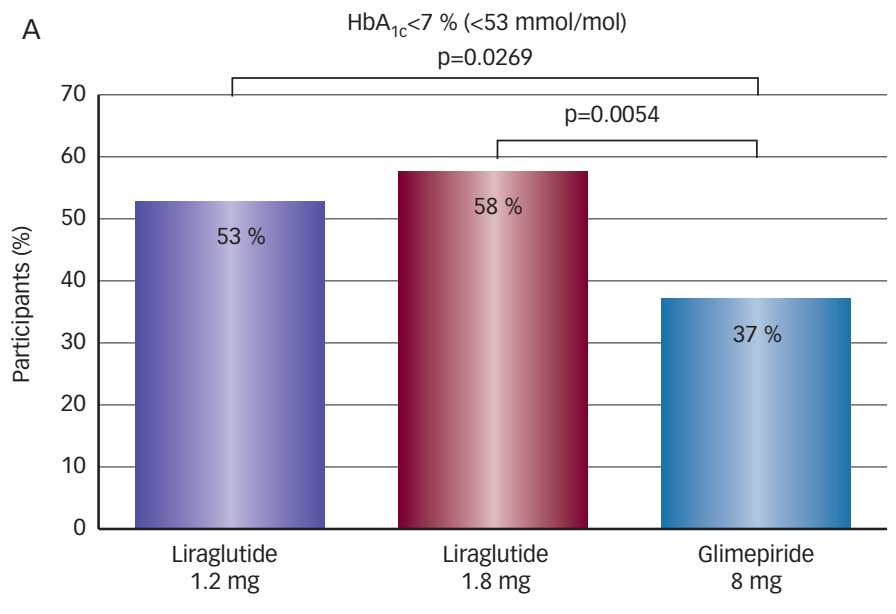

B

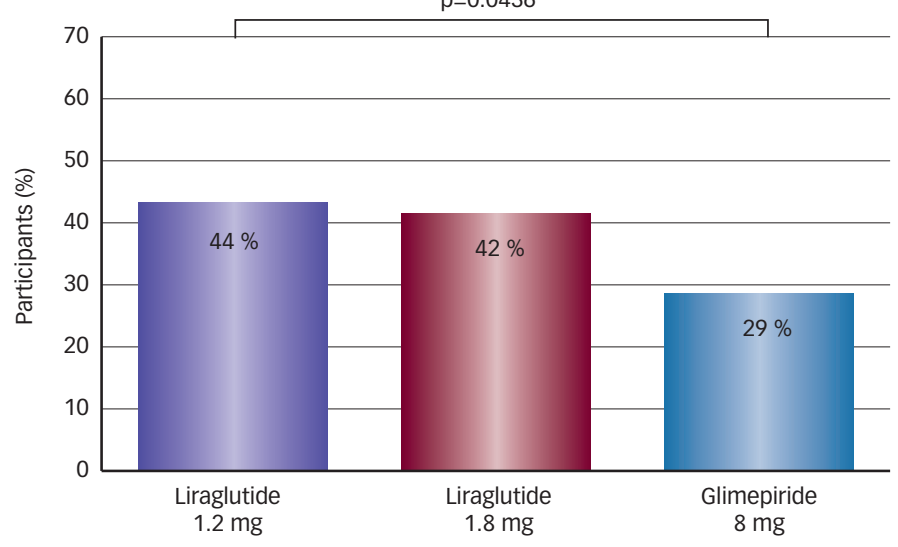

$H b A_{1 C}=$ glycosylated hemoglobin; $L E A D=$ Liraglutide effect and action in diabetes

the LEAD- 5 study of 581 patients with poorly controlled type 2 diabetes. Both FPG and PPG fell even more significantly with liraglutide versus placebo (treatment differences $-37.44 \mathrm{mg} / \mathrm{dl}$ and $-33.12 \mathrm{mg} / \mathrm{dl}$, respectively, both $\mathrm{p}<0.0001)$. This study also linked liraglutide with significantly better $\mathrm{HbA}_{1 \mathrm{c}}$ control than the active comparator, insulin glargine $(p=0.0015) .{ }^{59}$ These results should be interpreted with caution because an intensive treat-to-target approach might have produced more effective insulin glargine dosing. The patient-driven titration in this study was, however, consistent with real-life clinical experience (mean daily insulin glargine dose 24 International Units [IU] at end of study). ${ }^{59}$

\section{Head-to-head Trials of Incretin-based Therapies}

Data from some head-to-head trials of incretin-based therapies in type 2 diabetes are summarized in Table 3. A few trials have directly

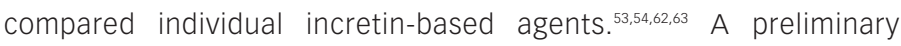
two-week comparison in 95 patients showed that exenatide twice daily produced greater reductions in post-prandial glucose and triglycerides than sitagliptin $\left(p<0.0001, p=0.0118\right.$, respectively). ${ }^{64}$ An eight-week cross-over RCT also reported significantly greater reductions in mean 24-hour and post-prandial glucose values with exenatide twice daily than with sitagliptin. ${ }^{65}$ 
Table 3: Head-to-head Clinical Trial Data for Incretin-based Therapies

\begin{tabular}{lll} 
Treatment & Effect of Treatment on: & \\
& $\mathrm{HbA}_{1 \mathrm{c}}$ & $\mathrm{FPG}$ \\
\hline Liraglutide $1.8 \mathrm{mg}$ qd & Liraglutide reduced mean & Liraglutide lowered mean \\
versus exenatide $10 \mathrm{\mu g}$ bid & $\mathrm{HbA}_{1 \mathrm{c}}$ more than exenatide & FPG more than exenatide \\
for 26 weeks & $(-1.12 \%$ [SE 0.08] versus & $(-28.98 \mathrm{mg} / \mathrm{dl}[\mathrm{SE} 0.20]$ \\
& $-0.79 \%$ [SE 0.08]; $\mathrm{p}<0.0001)$ & versus $-10.80 \mathrm{mg} / \mathrm{dl}[\mathrm{SE} 0.20] ;$ \\
& & $p<0.0001)$
\end{tabular}

\section{Body Weight}

Both led to similar weight

loss (-3.24 kg with

liraglutide versus $-2.87 \mathrm{~kg}$

with exenatide)

Adverse Effects and Reference

Both well tolerated, but less persistent nausea with liraglutide (estimated treatment rate ratio $0.448, p<0.0001$ ) and only minor hypoglycemia (1.93 versus 2.60 events for liraglutide and exenatide, repectively, per patient per year, $\mathrm{p}=0.0131)^{53}$

\begin{tabular}{|c|c|c|c|c|}
\hline $\begin{array}{l}\text { Test switching from } \\
\text { exenatide } 10 \mu \mathrm{g} \text { bid to } \\
\text { liraglutide } 1.8 \mathrm{mg} \text { qd or } \\
\text { remaining on liraglutide qd } \\
\text { for } 26 \text { weeks }\end{array}$ & $\begin{array}{l}\text { Switch to liraglutide further } \\
\text { reduced } \mathrm{HbA}_{1 \mathrm{C}}(-0.32 \% \text {, } \\
\mathrm{p}<0.0001)\end{array}$ & $\begin{array}{l}\text { Switch to liraglutide further } \\
\text { reduced FPG }(-16.2 \mathrm{mg} / \mathrm{dl} \text {, } \\
p<0.0001)\end{array}$ & $\begin{array}{l}\text { Switch to liraglutide further } \\
\text { reduced body weight } \\
(-0.9 \mathrm{~kg}, \mathrm{p}<0.0001)\end{array}$ & $\begin{array}{l}\text { Switch to liraglutide well tolerated, } \\
\text { with minor hypoglycemia ( } 1.30 \\
\text { episodes per patient per year) } \\
\text { or nausea ( } 3.2 \% \text { ) versus } 1.5 \% \\
\text { in those continuing liraglutide }\end{array}$ \\
\hline $\begin{array}{l}\text { Exenatide } 5 \mu \mathrm{g} \text { bid then } \\
10 \mu \mathrm{g} \text { bid versus sitagliptin } \\
100 \mathrm{mg} \text { qam for two weeks }\end{array}$ & NA & $\begin{array}{l}\text { Reduction similar with both } \\
\text { treatments }(-15 \mathrm{mg} / \mathrm{dl} \text { versus } \\
-19 \mathrm{mg} / \mathrm{dl})\end{array}$ & $\begin{array}{l}\text { Exenatide reduced body weight } \\
\text { more than sitagliptin }(-0.8 \mathrm{~kg} \\
\text { versus }-0.3 \mathrm{~kg}, \mathrm{p}=0.0056)\end{array}$ & $\begin{array}{l}\text { Mild to moderate gastrointestinal } \\
\text { adverse events with both } \\
\text { treatments }{ }^{64}\end{array}$ \\
\hline $\begin{array}{l}\text { Liraglutide } 1.2 \mathrm{mg} \text { or } \\
1.8 \mathrm{mg} \text { qd versus } \\
\text { sitagliptin } 100 \mathrm{mg} \text { qd } \\
\text { for } 26 \text { weeks }\end{array}$ & $\begin{array}{l}\text { Liraglutide lowered } \mathrm{HbA}_{1 \mathrm{c}} \text { more } \\
\text { than sitagliptin }(-1.24 \% \text { and } \\
-1.50 \% \text {, respectively, versus } \\
-0.90 \% \text {, both } \mathrm{p}<0.0001)\end{array}$ & $\begin{array}{l}\text { Mean decreases greater with } \\
\text { both doses of liraglutide than } \\
\text { with sitagliptin }(-33.66 \mathrm{mg} / \mathrm{dl} \\
\text { and }-38.52 \mathrm{mg} / \mathrm{dl} \text {, } \\
\text { respectively, versus } \\
-14.94 \mathrm{mg} / \mathrm{dl} \text {, both } \mathrm{p}<0.0001)\end{array}$ & $\begin{array}{l}\text { Weight loss greater with } \\
\text { both doses of liraglutide than } \\
\text { with sitagliptin }(-2.86 \mathrm{~kg} \text { and } \\
-3.38 \mathrm{~kg} \text {, respectively, versus } \\
-0.96 \mathrm{~kg}, p<0.0001)\end{array}$ & $\begin{array}{l}\text { Nausea more common with } \\
\text { liraglutide, similar frequency } \\
\text { of minor hypoglycemia for } \\
\text { all groups }{ }^{66}\end{array}$ \\
\hline $\begin{array}{l}\text { Participants continued the } \\
\text { above treatment of liraglutide } \\
1.2 \mathrm{mg} \text { or } 1.8 \mathrm{mg} \text { qd } \\
\text { versus sitaliptin } 100 \mathrm{mg} \text { qd } \\
\text { in a } 26 \text {-week extension }\end{array}$ & $\begin{array}{l}\text { Liraglutide lowered } \mathrm{HbA}_{1 \mathrm{C}} \text { more } \\
\text { than sitagliptin }(-1.29 \% \text { and } \\
-1.51 \% \text { versus }-0.88 \% \text {, both } \\
\mathrm{p}<0.0001)\end{array}$ & $\begin{array}{l}\text { Mean decreases greater with } \\
\text { both doses of liraglutide } \\
\text { than with sitagliptin } \\
(-30.78 \mathrm{mg} / \mathrm{dl} \text { and }-36.72 \mathrm{mg} / \mathrm{dl} \\
\text { versus }-10.62 \mathrm{mg} / \mathrm{dl} \text {, } \\
\text { both } p<0.0001)\end{array}$ & $\begin{array}{l}\text { Weight loss greater with } \\
\text { liraglutide than with sitagliptin } \\
(-2.78 \mathrm{~kg} \text { and }-3.68 \mathrm{~kg} \text { versus } \\
\text { versus }-1.16 \mathrm{~kg}, p<0.0001)\end{array}$ & $\begin{array}{l}\text { Minor hypoglycemia (8.1\%, } 8.3 \% \text {, } \\
\text { and } 6.4 \% \text { with liraglutide } 1.2 \mathrm{mg} \text {, } \\
\text { liraglutide } 1.8 \mathrm{mg} \text {, and sitagliptin, } \\
\text { respectively). Gastrointestinal } \\
\text { side effects (including nausea) } \\
\text { more frequently seen with } \\
\text { liraglutide, declined after } \\
\text { several weeks }{ }^{85}\end{array}$ \\
\hline $\begin{array}{l}\text { Exenatide } 2 \mathrm{mg} \text { qw } \\
\text { versus } \\
\text { liraglutide } 1.8 \mathrm{mg} \text { qd }\end{array}$ & $\begin{array}{l}\text { Liraglutide lowered } \mathrm{HbA}_{1 \mathrm{C}} \\
\text { more than exenatide qw } \\
(-1.48 \% \text { [SE 0.05] versus } \\
-1.28 \% \text { [SE 0.05]) }\end{array}$ & NA & $\begin{array}{l}\text { Weight loss greater } \\
\text { with liraglutide than } \\
\text { with exenatide qw } \\
(-3.58 \mathrm{~kg} \text { versus }-2.68 \mathrm{~kg})\end{array}$ & $\begin{array}{l}\text { Minor hypoglycemia ( } 10.8 \% \\
\text { and } 8.9 \% \text { with exenatide qw } \\
\text { and liraglutide, respectively). } \\
\text { Gastrointestinal side effects and } \\
\text { withdrawal due to adverse } \\
\text { events lower with exenatide } \text { qw }^{67}\end{array}$ \\
\hline
\end{tabular}
$A E=$ adverse event; $B i d=$ twice daily; $F P G$ = fasting plasma glucose; $H D A_{1 C}=$ glycosylated hemoglobin; $N A=$ not available; $q$ am = every morning; qd = once daily; $q \mathrm{~W}=$ once weekly; $S E=$ standard error.

Other studies have compared liraglutide directly with exenatide twice daily, and liraglutide directly with sitagliptin. 53,54,62,63,66 The LEAD-6 trial $(n=464)$ reported superior results for liraglutide over exenatide twice daily in $\mathrm{HbA}_{1 \mathrm{c}}$ reduction $(-1.12 \%$ versus $-0.79 \%$, respectively; $p<0.0001)$. The patients treated with liraglutide also reported significantly higher overall treatment satisfaction compared with the exenatide group ( $p=0004)$. Patients who switched from exenatide twice daily to liraglutide in the 14-week extension phase gained further improvements in $\mathrm{HbA}_{1 \mathrm{c}}$. Mean $\mathrm{A} 1 \mathrm{C}$ further decreased from $7.2 \%$ at Week 26 to $6.9 \%$ at Week $40(p<0.0001)$ after switching from exenatide to liraglutide, but remained similar with continued liraglutide (7.0 \% to $6.9 \% ; p=0.1222$ ). Figure 2 illustrates some of the therapeutic benefits of switching from exenatide twice daily to liraglutide in this study. ${ }^{54}$

Liraglutide $1.8 \mathrm{mg}$ or $1.2 \mathrm{mg}$ was linked with decreases of $1.50 \%$ and $1.24 \%$ in $\mathrm{HbA}_{1 \mathrm{c}}$ levels, respectively, from baseline in a 26-week trial of 665 metformin-treated patients, compared with a $0.90 \%$ reduction with sitagliptin $100 \mathrm{mg}$ (both liraglutide doses $p<0.0001$ versus sitagliptin).
A 26-week extension study revealed sustained efficacy of liraglutide versus sitagliptin, with significantly greater $\mathrm{HbA}_{1 \mathrm{c}}$ reductions from baseline at 52 weeks. Estimated mean treatment differences after one year were $-0.40 \%$ and $-0.63 \%$ with liraglutide $1.2 \mathrm{mg}$ and $1.8 \mathrm{mg}$, respectively, versus sitagliptin ( $p<0.0001$ for both comparisons). Adding $1.8 \mathrm{mg}$ liraglutide to metformin increased overall treatment satisfaction scores, which were significantly higher in the liraglutide groups than in the sitagliptin group (4.35 versus 2.96 point increase with liraglutide versus sitagliptin, respectively, $p=0.03)$, and this difference was maintained at 52 weeks (4.3 versus 3.0 point increase, respectively, $p=0.03$ ). ${ }^{66}$

In the trial to compare the efficacy and safety of exenatide once weekly versus liraglutide in patients with type 2 diabetes (DURATION-6), both treatment groups showed robust glycemic lowering with related weight loss. Reductions in $\mathrm{HbA}_{1 \mathrm{c}}$ and weight loss were greater with daily liraglutide injections, while gastrointestinal (GI) side effects and withdrawals due to adverse events were significantly lower with exenatide once weekly. ${ }^{67}$ 


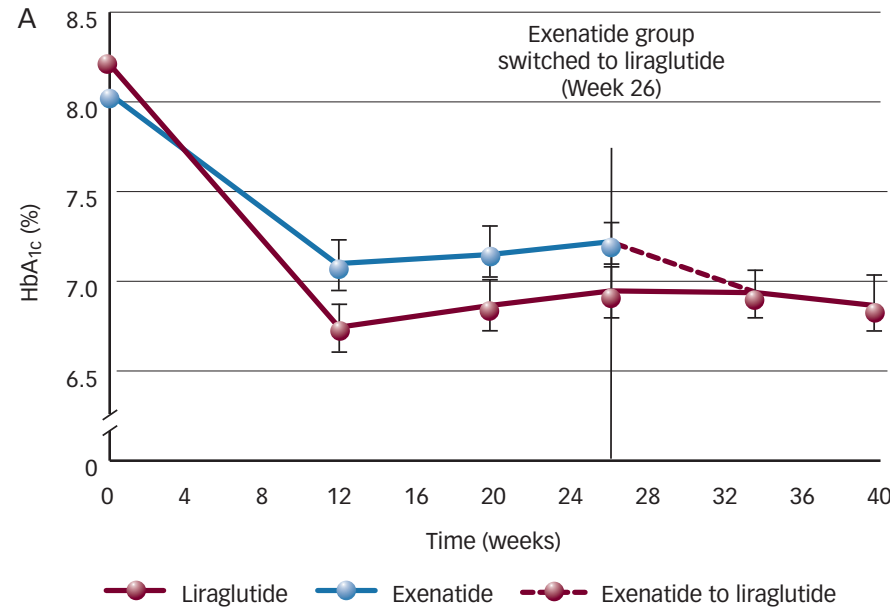

$\mathrm{HbA}_{1 \mathrm{c}}<7 \%$

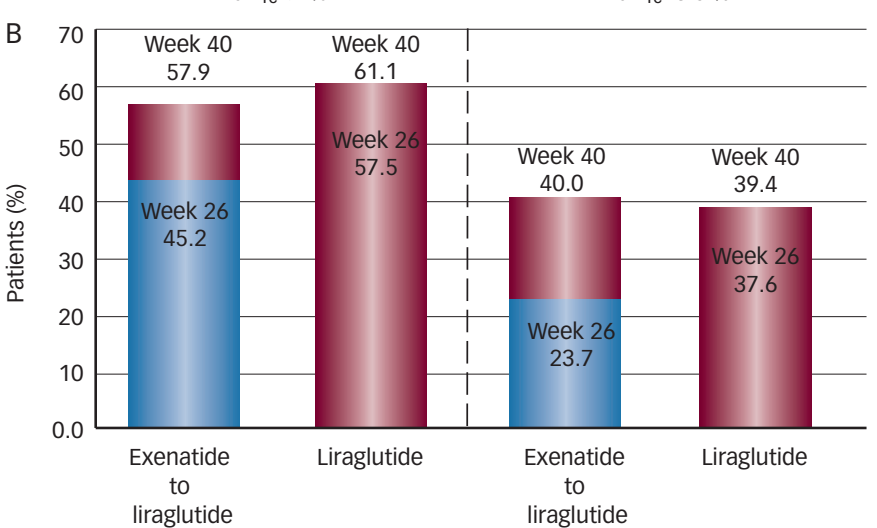

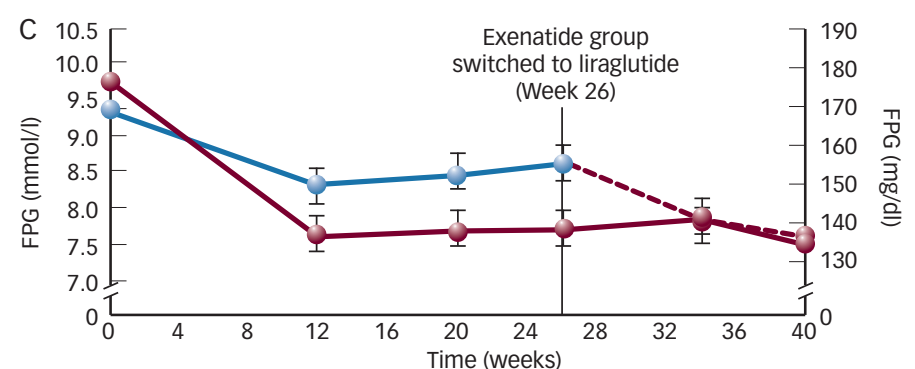

- Liraglutide - Exenatide - - Exenatide to liraglutide

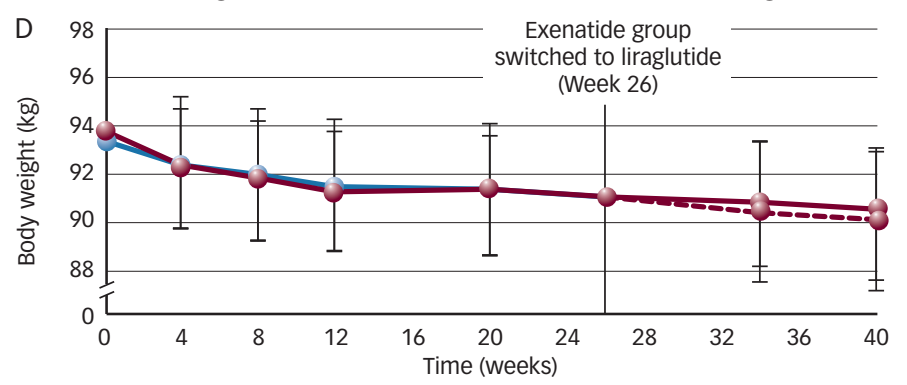

L Liraglutide $\quad-$ Exenatide - Exenatide to liraglutide

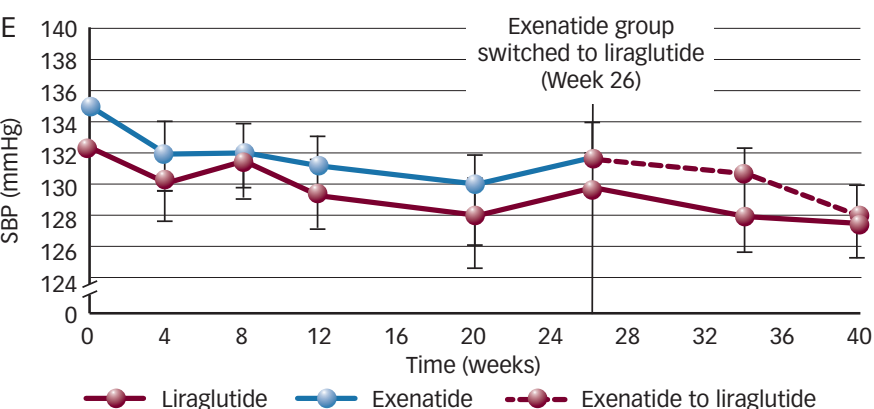

A: glycosylated hemoglobin ( $\mathrm{HbA}_{1}$ ) over time; B: percentage of patients reaching HbA liraglutide for 14 weeks); C: fasting plasma glucose (FPG) over time; D: body weight over time; E: systolic blood pressure (SBP) over time. Source: Buse et al., Diabetes Care, 2010.54 (C) 2010 by the Diabetes Association, reprinted here with permission.

\section{Safety Profiles of Incretin-based Therapies}

In clinical trials, adverse events (AES) occuring with GLP-1 receptor agonists and DPP-4 inhibitors have been predominantly mild to moderate, with incidences generally similar to those seen with placebo. ${ }^{20-40,43-60,62-64}$ All three approved DPP-4 inhibitors are associated with increased rates of nasopharyngitis (up to $6.9 \%$ ) and headache (up to $6.5 \%$ ). ${ }^{6-8}$ Other AEs in clinical trials included upper respiratory tract infections (up to $6.3 \%$ and $7.7 \%$ with sitagliptin and saxagliptin, respectively). ${ }^{6.8}$ Typical AEs in GLP-1 receptor agonist-treated patients are GI AEs, such as nausea, vomiting, and diarrhea. ${ }^{5,9}$ Post-marketing surveillance has identified a few rare but serious AEs in patients receiving incretin-based therapy, including severe hypoglycemia when incretin-based therapy is used in combination with either sulfonylureas or insulin, and pancreatitis. Thyroid C-cell tumors (see 'Thyroid C-cell Tumor' section on page 91) with GLP-1 receptor agonists were identified in rodent studies, but human relevance has not been established. Some DPP-4 inhibitors have warnings about rare, severe hypersensitivity reactions. ${ }^{6-8}$

\section{Dipeptidyl Peptidase-4 Inhibitors}

Sitagliptin

Phase III clinical trial data linked sitagliptin monotherapy with fewer GI AEs than metformin (11.6 \% versus $20.7 \%$, respectively). ${ }^{20}$ Diarrhea and nausea occurred significantly more often in patients taking metformin than in patients taking sitagliptin (3.6\% versus $10.9 \%$ $[p<0.001]$ and $1.1 \%$ versus $3.1 \%$ [ $p=0.032]$, respectively). ${ }^{20}$ Adding sitagliptin to metformin had little impact on AEs, which tended to increase with rising metformin dose, at up to two years' follow-up. ${ }^{21-23}$ The number of patients discontinuing sitagliptin as an adjunct to pioglitazone due to clinical AEs (5.7\% versus $1.1 \%$ ) and the incidence of abdominal pain (3.4\% versus $0 \%$ ) were significantly greater in the sitagliptin group compared with the placebo group (both $p<0.05$ ), although these AEs were considered unrelated to the study drug. ${ }^{29}$

\section{Saxagliptin}

Saxagliptin $2.5 \mathrm{mg}, 5.0 \mathrm{mg}$, and $10 \mathrm{mg}$ doses all had similar AE frequencies than placebo in a phase III monotherapy trial..$^{40}$ Similarly, $A E$ rates were similar across study groups in trials of saxagliptin in combination regimens with metformin, glyburide, or thiazolidinedione..$^{35,36,39,41} \mathrm{AE}$ rates in extension studies remained similar for up to 76 weeks in patients receiving thiazolidinedione as monotherapy or $2.5 \mathrm{mg}$ or $5.0 \mathrm{mg}$ saxagliptin, and in patients receiving saxagliptin monotherapy, metformin monotherapy, or a combined regimen of saxagliptin and metformin. ${ }^{36,39}$ 


\section{Linagliptin}

Linagliptin showed an overall incidence of AEs that was comparable to that observed with placebo in the monotherapy trials, ${ }^{43,46}$ with the most frequent AEs reflecting those observed with other DPP-4 inhibitors. ${ }^{44,45}$

\section{Glucagon-like Peptide-1 Receptor Agonists Exenatide}

Only one treatment-emergent AE-nausea-was significantly higher with exenatide twice daily monotherapy versus placebo (8\% versus $0 \%$ in the exenatide and placebo groups, respectively $[p=0.010]){ }_{.}^{48}$ The main AEs in exenatide twice-daily trials were GI AEs that were mild to moderate in intensity; the results also suggested that GI side effects were dose-dependent. ${ }^{49-51}$ In one trial of exenatide twice daily $10 \mu \mathrm{g}$ in combination with a thiazolidinedione, there were 19 (15.7\%) withdrawals for AEs (mainly nausea and/or vomiting) with exenatide versus two (1.8\%) withdrawals for AEs with placebo..$^{52}$ In that study, most AEs were mild to moderate. Starting exenatide twice daily therapy at the higher dose of $10 \mu \mathrm{g}$ is not recommended due to these dose-related side effects, and physicians are advised to allow one month for GI AEs to diminish before increasing the dose. ${ }^{5}$ The head-to-head comparator trial of exenatide twice daily versus sitagliptin reported higher incidences of nausea and vomiting in patients taking exenatide (34\% and $24 \%$, respectively) compared with sitagliptin (12\% and $3 \%$, respectively). ${ }^{64}$ However, this study allowed only one week before titrating to the higher exenatide twice daily dose of $10 \mathrm{\mu g}$, instead of the recommended one month. ${ }^{5}$

\section{Liraglutide}

As with exenatide, the most common AEs in liraglutide-treated patients were $\mathrm{Gl}$. Incidences in the six LEAD studies ranged from $10.5 \%$ to $44 \%$ for nausea, $4.4 \%$ to $17 \%$ for vomiting, and $4 \%$ to $18.7 \%$ for diarrhea. ${ }^{53-60}$ GI side effects were generally mild to moderate and often transient; for example, one study reported 216 vomiting events in the first four weeks with liraglutide, compared with only 65 events during the subsequent 22 weeks. $^{60}$ Direct comparator studies have compared the tolerability and safety profiles of liraglutide against those of both sitagliptin and exenatide twice daily. ${ }^{53,66}$ Nausea was more common in liraglutide-treated patients versus sitagliptin, but it was also more transient and affected less than $4 \%$ of patients in all treatment groups by the end of the study. ${ }^{66}$ The LEAD-6 study reported no major hypoglycemic episodes with liraglutide, with minor hypoglycemic event rates of 1.932 versus 2.600 events per patient per year with liraglutide versus exenatide twice daily, respectively (rate ratio $=0.55, p=0.013$ ). Initial nausea incidences were similar with both agents but, by Week 26 , only $3 \%$ of patients taking liraglutide were affected compared with $9 \%$ of patients taking exenatide twice daily. ${ }^{53}$

\section{Hypoglycemia}

When incretin-based agents are used as monotherapy, the incidence and severity of hypoglycemia is low and generally similar to those observed with placebo, but the hypoglycemia risk may increase with combination regimens, particularly when sulfonylureas or insulin are included. . $^{20-40,43-60,62-64}$

\section{Sitagliptin}

RCTs have reported hypoglycemia incidences of up to $3 \%$ for sitagliptin monotherapy with no apparent increased hypoglycemia risk for the drug in combination with metformin or pioglitazone. ${ }^{19-21,23,29}$ Sitagliptin has been linked with significantly less hypoglycemia than glipizide (50 episodes in 29 [4.9\%] patients versus 657 episodes in 187 [32\%] patients receiving sitagliptin and glipizide, respectively). ${ }^{25}$ Adding sitagliptin to insulin doubled hypoglycemia rates compared with placebo (16\% versus $8 \%$ ). ${ }^{32}$

\section{Saxagliptin}

Confirmed hypoglycemic episodes were rare in both saxagliptin monotherapy studies, affecting up to $0.6 \%$ of subjects. ${ }^{34,37}$ Fewer saxagliptin-treated patients experienced hypoglycemia compared with glipizide as an adjunct to metformin treatment over 52 weeks (3.0\% versus $36.3 \%$; $p<0.0001) .{ }^{35}$ Confirmed hypoglycemia events remained rare after 76 weeks of treatment with saxagliptin plus thiazolidinedione. ${ }^{36}$

\section{Linagliptin}

There was no excess of hypoglycemic episodes with linagliptin monotherapy versus placebo and no patient required third-party intervention. ${ }^{43}$ Hypoglycemia affected three patients $(0.6 \%)$ taking metformin plus linagliptin and five patients $(2.8 \%)$ in the metformin plus placebo group. ${ }^{44} \mathrm{~A}$ trial comparing linagliptin versus placebo or glimepiride reported no hypoglycemic events for linagliptin or placebo, but three patients (5\%) experienced hypoglycemia in the glimepiride group. ${ }^{45}$

\section{Exenatide Twice Daily}

RCTs revealed no significant increase in the incidence of hypoglycemia in patients taking exenatide twice daily as monotherapy, or taking exenatide combined with metformin, thiazolidinediones, or metformin plus thiazolidinediones. ${ }^{48,50,52}$ However, adding exenatide twice daily to a sulfonylurea may increase the incidence of hypoglycemia (reported incidences of $14 \%$ and $36 \%$ for a sulfonylurea combined with exenatide twice daily $5 \mu \mathrm{g}$ or $10 \mu \mathrm{g}$, respectively, compared with $3 \%$ for a sulfonylurea alone). ${ }^{49}$ The incidence of hypoglycemia also increased when exenatide twice daily was added to a sulfonylurea plus metformin (19.2 \%, $27.8 \%$, and $12.6 \%$ for exenatide twice daily $5 \mu \mathrm{g}, 10 \mu \mathrm{g}$, and placebo, respectively). ${ }^{51,52}$

\section{Liraglutide}

Major hypoglycemic episodes were extremely rare in liraglutide studies, and occurred in most cases with a concomitant sulfonylurea, while minor hypoglycemia affected between 3-26\% of liraglutide-treated patients. ${ }^{53-56,58-60}$ Rates of minor hypoglycemia were significantly higher in patients taking $1.2 \mathrm{mg}$ or $1.8 \mathrm{mg}$ liraglutide than in patients taking rosiglitazone in one study, and significantly lower than with glimepiride or exenatide twice daily in three other studies. . $33,55,57,61^{-1}$

\section{Pancreatitis}

A small number of patients treated with incretin-based therapies have developed acute pancreatitis during clinical trials, and post-marketing surveillance reports have led to FDA warnings about the risk of acute pancreatitis with exenatide twice daily, sitagliptin, saxagliptin, and liraglutide. ${ }^{5,6,8,9}$ Pancreatitis has also been reported during linagliptin clinical trials. ${ }^{7}$ However, a causal link between incretin-based therapies and pancreatitis has not been established. Large-scale analyses of healthcare databases and pooled clinical trial data suggest that the risk of pancreatitis in patients with type 2 diabetes receiving incretin-based therapy is comparable to that of patients with type 2 diabetes not receiving incretin-based agents. The incidence of pancreatitis was three times higher in individuals with type 2 diabetes than in people without 
Table 4: Ongoing Clinical Trials Regarding Incretin-based Therapies and Cardiovascular Risk

\begin{tabular}{|c|c|c|c|c|c|}
\hline Trial Name & Treatment & Current Status & $\begin{array}{l}\text { Number of } \\
\text { Subjects (n) }\end{array}$ & $\begin{array}{l}\text { Expected } \\
\text { Completion Date }\end{array}$ & Clinical Trials Website Link \\
\hline LEADERTM $^{T M}$ & Liraglutide & $\begin{array}{l}\text { Still recruiting } \\
\text { participants }\end{array}$ & 8,754 & January 2016 & $\begin{array}{l}\text { http://clinicaltrials.gov/ct2/show/NCT01179048 } \\
\text { Accessed } 4 \text { December, } 2011\end{array}$ \\
\hline ELIXA & $\begin{array}{l}\text { Lixisenatide } \\
\text { (AVE0010) }\end{array}$ & $\begin{array}{l}\text { Still recruiting } \\
\text { participants }\end{array}$ & 6,000 & October 2013 & $\begin{array}{l}\text { http://clinicaltrials.gov/ct2/show/NCT01147250 } \\
\text { Accessed } 4 \text { December, } 2011\end{array}$ \\
\hline REWIND & Dulaglutide & $\begin{array}{l}\text { Still recruiting } \\
\text { participants }\end{array}$ & 9,622 & April 2019 & $\begin{array}{l}\text { http://clinicaltrials.gov/ct2/show/NCT01394952 } \\
\text { Accessed } 4 \text { December, } 2011\end{array}$ \\
\hline EXSCEL & $\begin{array}{l}\text { Exenatide } \\
\text { once weekly }\end{array}$ & $\begin{array}{l}\text { Still recruiting } \\
\text { participants }\end{array}$ & 9,500 & March 2017 & $\begin{array}{l}\text { http://clinicaltrials.gov/ct2/show/NCT01144338 } \\
\text { Accessed } 4 \text { December, } 2011\end{array}$ \\
\hline EXAMINE & Alogliptin & $\begin{array}{l}\text { Still recruiting } \\
\text { participants }\end{array}$ & 5,400 & December 2014 & $\begin{array}{l}\text { http://clinicaltrials.gov/ct2/show/NCT00968708 } \\
\text { Accessed } 4 \text { December, } 2011\end{array}$ \\
\hline SAVOR-TIMI 53 & Saxagliptin & $\begin{array}{l}\text { Still recruiting } \\
\text { participants }\end{array}$ & 16,500 & April 2014 & $\begin{array}{l}\text { http://clinicaltrials.gov/ct2/show/NCT01107886 } \\
\text { Accessed } 4 \text { December, } 2011\end{array}$ \\
\hline TECOS & Sitagliptin phosphate & $\begin{array}{l}\text { Still recruiting } \\
\text { participants }\end{array}$ & 14,000 & December 2014 & $\begin{array}{l}\text { http://clinicaltrials.gov/ct2/show/NCT00790205 } \\
\text { Accessed } 4 \text { December, } 2011\end{array}$ \\
\hline
\end{tabular}

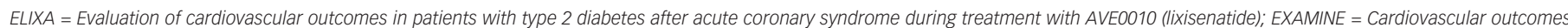

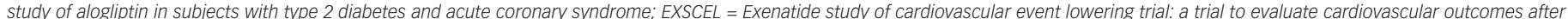

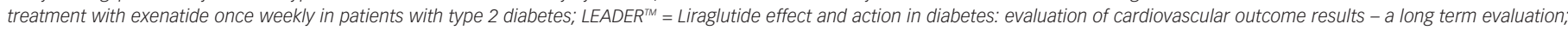
REWIND = Researching cardiovascular events with a weekly incretin in diabetes; SAVOR-TIMI $53=$ Does saxagliptin reduce the risk of cardiovascular events when used alone or added to other diabetes medications; TECOS = Sitagliptin cardiovascular outcome study.

diabetes, even without DPP-4 inhibitor or GLP-1 receptor agonist therapy. ${ }^{68,69}$ Preclinical studies reported pancreatitis in small numbers of rats that had lost $30 \%$ of body weight (an established risk factor for pancreatitis) taking GLP-1 receptor agonists. ${ }^{68}$ Larger in vivo studies failed to confirm any link between GLP-1 receptor agonists and pancreatitis, and there are even data suggesting a protective effect. ${ }^{68}$ Long-term clinical trial data are needed to clarify what effect incretin-based therapy may have on pancreatitis risk. However, incretin-based therapies should not be used in patients with risk factors for pancreatitis (e.g., gallstones, excessive alcohol use, high triglycerides) and should be discontinued if pancreatitis is suspected. Diagnosis of pancreatitis should be confirmed by established criteria, not by raised levels of pancreatic enzymes alone.

\section{Thyroid C-Cell Tumor}

GLP-1 receptor agonist treatment may cause the development of thyroid $\mathrm{C}$-cell hyperplasia and neoplasia in rodents. However, long-term clinical trials of sufficient size and duration to allow conclusions to be drawn regarding cancer and incretin therapeutics have not yet been completed..$^{68}$ Liraglutide has received a black box warning against its use in patients with a family history of medullary thyroid carcinoma or multiple endocrine neoplasia syndrome type 2 . The considerable differences in the biology of rodent and human thyroid GLP-1 receptor systems have led regulatory authorities to conclude that the risk of humans taking GLP-1 receptor agonists developing medullary thyroid cancer is low and difficult to quantify. ${ }^{70}$ Compared with the high levels of rodent C-cells, human C-cells have barely detectable levels of GLP-1 receptors. ${ }^{71}$ As with any new drug class, the long-term effects of GLP-1 receptor agonists and DPP-4 inhibitors in humans will require further investigation.

\section{Impact on Body Weight}

Studies have linked GLP-1 receptor agonists with progressive and sustained weight loss, although DPP-4 inhibitors are typically weight neutral; other studies have reported weight gain or weight loss. ${ }^{10,23,53-60}$ However, a meta-analysis of 13 DPP-4 inhibitor trials identified a small weight increase compared with placebo, so the precise effect of these drugs on body weight remains unclear.

A meta-analysis of eight GLP-1 receptor agonist studies revealed a $-2.37 \mathrm{~kg}$ weighted mean difference (WMD) versus comparators, with a WMD of $-1.44 \mathrm{~kg}$ for exenatide twice daily versus placebo.$^{10}$ In the LEAD trial program, placebo-subtracted body weight losses were $0.1 \mathrm{~kg}$, $1.3 \mathrm{~kg}, 2.6 \mathrm{~kg}$, and $1.38 \mathrm{~kg}$ with liraglutide. ${ }^{57-60}$ Comparator-subtracted weight losses were $2.3 \mathrm{~kg}$ versus rosiglitazone $(p<0.0001), 3-3.8 \mathrm{~kg}$ versus glimepiride $(p \leq 0.0038)$, and $3.4 \mathrm{~kg}$ versus insulin glargine. ${ }^{55-59}$

In the LEAD-3 trial, liraglutide monotherapy produced dose-dependent and sustained weight loss for two years. Estimated treatment differences versus glimepiride were $-3.24 \mathrm{~kg}$ and $-3.78 \mathrm{~kg}$ for $1.2 \mathrm{mg}$ and $1.8 \mathrm{mg}$ liraglutide, respectively (both $p<0.0001) .{ }^{56}$ Exenatide twice daily was also linked with dose-dependent weight loss with no plateau up to the end of a 30-week RCT (placebo-subtracted weight loss at study end: $1.0 \mathrm{~kg}$ [ $p<0.05$ versus placebo]). ${ }^{49}$ In a direct comparator trial, the difference in weight loss between exenatide twice daily and liraglutide (2.87 kg versus $3.24 \mathrm{~kg}$, respectively) was non-significant after 26 weeks. ${ }^{53}$ Weight loss continued in a 14-week extension to this study - a further $0.4 \mathrm{~kg}$ in patients continuously receiving liraglutide and $0.9 \mathrm{~kg}$ in patients who switched from exenatide twice daily to liraglutide at 26 weeks. ${ }^{54}$

Weight loss with GLP-1 receptor agonists could, in theory, be related to nausea, which is one of the most common side effects of this therapeutic class. Nausea was largely transient, however, and declined sharply after the first few weeks, while weight loss was sustained

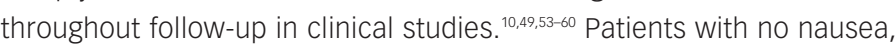
or no Gl side effects lasting more than one week, can also lose weight while taking a GLP-1 receptor agonist. ${ }^{10,72}$

It seems likely that weight loss with GLP-1 receptor agonists is due to enhanced recognition of satiety, leading to reduced food intake. 
Post-meal increases in endogenous GLP-1 are linked with increased blood supply to the prefrontal cortex and hypothalamus in humans, an indication of neuronal activity in areas controlling satiety and food intake. ${ }^{73}$ Clinical data also support reduced calorie intake during GLP-1 receptor agonist therapy. ${ }^{64,65}$

\section{Potential Cardioprotection}

GLP-1 receptor agonist therapy may exert a cardioprotective effect in type 2 diabetes. A database study of 39,275 patients treated with exenatide twice daily and 381,218 patients receiving other antihyperglycemic drugs linked GLP-1 therapy with reduced cardiovascular events (hazard ratio [HR]: 0.81, $p=0.01$ ), reduced hospital admissions for cardiovascular events (HR: 0.88, $p=0.02$ ), and reduced all-cause hospital admissions (HR: 0.94, $p<0.001) .{ }^{74}$ Robust clinical trial data are required to confirm whether incretin-based therapies are cardioprotective in type 2 diabetes; several studies are under way (see Table 4).

\section{Comparison of Incretin-based Therapies}

DPP-4 inhibitors have rapidly gained position among the oral antidiabetic treatments. This is due to their ease of use, lack of any increase in weight, minor hypoglycemia risk, apparently benign AE profile, and good tolerability. The GLP-1 receptor agonists exenatide twice daily and liraglutide also offer a low hypoglycemia risk and a good tolerability/safety profile. Unlike the DPP-4 inhibitors, the two approved GLP-1 receptor agonists are injected but, although this might appear to be less convenient or attractive for patients, they offer the added benefit of long-term sustained weight loss. Indeed, an assumed patient preference for oral treatments may reflect prescriber perceptions rather than actual patient preferences. RCT data revealed significantly higher overall treatment satisfaction with liraglutide than with sitagliptin, despite the latter having an oral mode of administration. ${ }^{62}$

\section{Pharmacokinetic Considerations}

Both sitagliptin and saxagliptin are primarily eliminated via the kidney; therefore, dose reductions are required in patients with moderate or severe renal impairment (saxagliptin has not been studied in patients receiving dialysis). This is highly relevant for the type 2 diabetes population, of whom about $40 \%$ have chronic kidney disease (CKD) according to data from the Fourth National Health and Nutrition Examination Survey (NHANES IV); also, elderly patients may have normal serum creatinine levels but 'concealed' impaired glomerular filtration. ${ }^{75,76}$ In contrast, the kidney accounts for only $5 \%$ of linagliptin excretion, so no dose adjustments are required in patients with renal impairment. Linagliptin clearance is via the liver, so drugs that induce cytochrome $\mathrm{P} 450$, isozyme CP3A4, or P-glycoprotein (P-gp) are likely to reduce linagliptin exposure to subtherapeutic levels. ${ }^{7}$ Linagliptin should not be used in patients who require CP3A4 or P-gp inducers such as rifampin.?

No dose adjustments in patients with renal impairment are required for either exenatide twice daily or liraglutide, although both drugs should be used with caution in this population. ${ }^{5.9}$ Exenatide is not recommended in patients with severe renal impairment or end-stage renal disease (ESRD), and physicians should be cautious about giving exenatide twice daily doses of $5 \mu \mathrm{g}$ or more to patients with moderate renal impairment. ${ }^{5}$ Current advice is to use liraglutide with caution in patients with renal impairment, following post-marketing reports of raised serum creatinine, acute renal failure, or worsening of chronic renal failure. ${ }^{9}$ A meta-analysis of the six LEAD phase III RCTs concluded that the efficacy and safety profile of liraglutide was unaffected by mild renal impairment. ${ }^{77}$

Both GLP-1 receptor agonists and DPP-4 inhibitors are novel classes of drugs, and careful long-term monitoring and post-marketing surveillance for any unexpected AEs are required. Further data are required to confirm whether GLP-1 receptor agonists or DPP-4 inhibitors do increase pancreatitis risk. In the meantime, it seems prudent to assume that, if there is a causative link, it may be a class effect, and caution should be used when prescribing GLP-1 receptor agonists or DPP-4 inhibitors, particularly in patients with pre-existing pancreatitis.

\section{Implications of Clinical Trial Data}

Typical considerations for most patients with type 2 diabetes would be efficacy, hypoglycemia, impact on body weight, and common AEs. Incretin-based therapies have shown minimal risk of hypoglycemia when used as monotherapy. Combining DPP-4 inhibitors or GLP-1 receptor agonists with other antihyperglycemic agents such as sulfonylureas has been linked with increased hypoglycemia rates, but reducing sulfonylurea doses may mitigate this risk.

DPP-4 inhibitors appear to be weight neutral, while GLP-1 receptor agonists are linked with long-term weight loss, which is an attractive characteristic for both physicians and patients that could optimize treatment adherence. GI side effects such as nausea may prove limiting for some patients, but clinical trials have demonstrated that nausea declines rapidly during the first few weeks of liraglutide treatment. LEAD-6 study data suggest that nausea may subside earlier with liraglutide than with exenatide twice daily..$^{53}$ Interestingly, 382 patients with type 2 diabetes who participated in an online survey ranked efficacy (measured by $\mathrm{HbA}_{1 \mathrm{C}}$ ) as the most important of four factors determining preference for a hypothetical GLP-1 receptor agonist, ahead of nausea, hypoglycemia, and dosing schedule; $96 \%$ of patients preferred the product profile of liraglutide to the product profile of exenatide twice daily, based on clinical trial data. ${ }^{78}$

Both liraglutide and exenatide twice daily have shown superior efficacy (including $\mathrm{HbA}_{1 \mathrm{c}}$ reductions) compared with sitagliptin in direct comparator trials. ${ }^{64-66}$ Within the GLP-1 receptor agonists class, the phase III LEAD-6 trial revealed significantly greater $\mathrm{HbA}_{1 \mathrm{c}}$ reduction and treatment satisfaction for liraglutide versus exenatide twice daily. ${ }^{54}$ Results of a meta-analysis of seven trials $(n=4,625)$ were consistent with the head-to-head comparator studies: $40 \%$ and $32 \%$ of patients receiving liraglutide $1.8 \mathrm{mg}$ or $1.2 \mathrm{mg}$, respectively, achieved a pre-specified composite endpoint of $\mathrm{HbA}_{1 \mathrm{c}}<7.0 \%$ without weight gain or hypoglycemia. ${ }^{79}$ The same composite endpoint occurred in 6-25\% of comparators, including $25 \%$ with exenatide twice daily and $11 \%$ with sitagliptin. ${ }^{79}$

\section{Discussion}

Type 2 diabetes is a complex disease that involves multiple, interrelated metabolic processes. Patients are often overweight and have other cardiovascular risk factors such as dyslipidemia. Tight glycemic control is achievable using maximized doses of 
antihyperglycemic drugs, but weight gain is a common side effect of many of these treatments that, in turn, increases cardiovascular risk. Incretin-based therapies offer effective glycemic control, and could offer additional cardioprotective benefits. Clinical studies have consistently reported weight loss with the GLP-1 receptor agonists exenatide and liraglutide. Reducing body weight offers potential metabolic improvements in addition to glycemic control.

Adherence to treatment is crucial for effective disease management in type 2 diabetes, and achieving good adherence to treatment can be a major challenge. It seems logical to assume that regular self-injection might be a barrier to adherence, and expect oral antihyperglycemic drugs to be more acceptable to patients than injectable agents. Evidence suggests, however, that patient satisfaction with treatment is more strongly linked to efficacy than to the mode of administration. .2,78 $^{2}$ Rapid and sustained weight loss, as reported in liraglutide clinical trials, may also encourage adherence.

Ongoing trials continue to investigate the impact GLP-1 receptor agonists and DPP-4 inhibitors have on cardiovascular disease and other comorbidities associated with diabetes that may result from weight loss alone, or weight loss in combination with other cardioprotective effects.

The MOA of these agents is glucose-dependent, so their effect is attenuated with normoglycemia, potentially minimizing the risk of hypoglycemia. Clinical trials have confirmed that there is a relatively low risk of severe hypoglycemic episodes using incretin-based agents, although this risk does increase when an incretin-based agent is used in combination with a sulfonylurea.

Incretin-based therapies offer effective control of both FPG and PPG, and hence $\mathrm{HbA}_{1 \mathrm{c}}$, with acceptable tolerability. The risk of serious hypoglycemic episodes is low, except for combination therapies with a sulfonylurea, in which case lowering the sulfonylurea dose is recommended. The two currently available GLP-1 receptor agonists are linked with weight loss; DPP-4 inhibitors are generally described as weight neutral, although this remains unclear. Trials are under way to clarify whether therapy with GLP-1 receptor agonists or DPP-4 inhibitors exhibit a direct cardioprotective effect. There are concerns about potential rare, serious AEs such as pancreatitis, although no causative link has yet been established. Patients with risk factors such as a history of pancreatitis should not receive these agents until further data become available. For most patients with type 2 diabetes, however, GLP-1 receptor agonists and DPP-4 inhibitors offer a useful addition to current therapeutic options.

\section{Future Developments}

GLP-1 receptor agonists and DPP-4 inhibitors are incretin-based agents characterized by glucose-dependent actions. This allows them to have differential potency of glycemic effects, depending on ambient glucose levels. The clinical differences between the two classes of agents highlight the potential for new therapies with different targets. The need for daily injections could make GLP-1 receptor agonists less appealing to some patients than oral formulations. However, this is balanced by a more potent glucose-lowering effect than DPP-4 inhibitors as well as beneficial weight loss effects. Developing oral formulations or once-weekly (or less frequent) injectable formulations could make these therapies more convenient.

Accumulating evidence in recent years supports the potential for incretin-based therapies to improve prognoses for patients whose diabetes is poorly controlled by other medications. Incretin-based agents may, in future, be used even earlier in the treatment of type 2 diabetes. They may also prove valuable in the management of type 1 diabetes. ${ }^{80-82}$
1. CDCP CfDCaP, National Diabetes Fact Sheet: national estimates and general information on diabetes and prediabetes in the United States, 2011. Atlanta, GA: U.S. Department of Health and Human Services, Centers for Disease Control and Prevention, 2011.

2. UKPDS, Intensive blood-glucose control with sulphonylureas or insulin compared with conventional treatment and risk of complications in patients with type 2 diabetes (UKPDS 33). UK Prospective Diabetes Study (UKPDS) Group, Lancet, 1998:352:837-53.

3. Gross JL, Kramer CK, Leitao CB, et al., Effect of antihyperglycemic agents added to metformin and a sulfonylurea on glycemic control and weight gain in type 2 diabetes: a network meta-analysis, Ann Intern Med, 2011;154:672-9.

4. Nathan DM, Buse JB, Davidson MB, et al., Medical management of hyperglycemia in type 2 diabetes: a consensus algorithm for the initiation and adjustment of therapy: a consensus statement of the American Diabetes Association and the European Association for the Study of Diabetes, Diabetes Care 2009;32:193-203.

5. Amylin, Byetta (exenatide BID) [prescribing information], San Diego, CA: Amylin Pharmaceuticals, Inc, 2010.

6. BMS, Onglyza (saxagliptin) [prescribing information], Princeton, $\mathrm{NJ}$ : Bristol-Myers Squibb Co, 2011.

7. Boehringer, Tradjenta (linagliptin) [prescribing information], Ridgefield, CT: Boehringer Ingelheim Pharmaceuticals, Inc 2011.

8. Merck, Januvia (sitagliptin) [prescribing information] Whitehouse Station, NJ: Merck \& Co Inc, 2010

9. Novo, Victoza (liraglutide) [prescribing information], Princeton, NJ: Novo Nordisk Inc, 2011

10. Amori RE, Lau J, Pittas AG, Efficacy and safety of incretin therapy in type 2 diabetes: systematic review and metaanalysis, JAMA, 2007;298:194-206.

11. Drucker DJ, Enhancing incretin action for the treatment of type 2 diabetes, Diabetes Care, 2003;26:2929-40.

12. Vilsboll T, Krarup T, Madsbad S, et al., Defective amplification of the late phase insulin response to glucose by GIP in obese Type II diabetic patients, Diabetologia, 2002:45:1111-9.

13. Nauck MA, Heimesaat MM, Orskov $C$, et al, Preserved incretin activity of glucagon-like peptide 1 [7-36 amide] but not of synthetic human gastric inhibitory polypeptide in patients with type-2 diabetes mellitus, I Clin Invest, 1993;91:301-7.

14. Herman GA, Bergman A, Stevens C, et al., Effect of single oral doses of sitagliptin, a dipeptidyl peptidase-4 inhibitor, on incretin and plasma glucose levels after an oral glucose tolerance test in patients with type 2 diabetes, I Clin Endocrinol Metab, 2006;91:4612-9.

15. Agersø H, Jensen LB, Elbrønd B, et al., The pharmacokinetics, pharmacodynamics, safety and tolerability of NN2211, a new long-acting GLP-1 derivative, in healthy men, Diabetologia, 2002;45:195-202.

16. Meier JJ, Gallwitz B, Siepmann N, et al., Gastric inhibitory polypeptide (GIP) dose-dependently stimulates glucagon secretion in healthy human subjects at euglycaemia, Diabetologia, 2003;46:798-801.

17. Näslund E, Bogefors J, Skogar S, et al., GLP-1 slows solid gastric emptying and inhibits insulin, glucagon, and PYY release in humans, Am J Physiol, 1999;277:R910-6.

18. Mentis N, Vardarli I, Köthe LD, et al., GIP does not potentiate the antidiabetic effects of GLP-1 in hyperglycemic patients with type 2 diabetes, Diabetes, 2011;60:1270-6.

19. Raz I, Hanefeld M, Xu L, et al., Efficacy and safety of the dipeptidyl peptidase-4 inhibitor sitagliptin as monotherapy in patients with type 2 diabetes mellitus, Diabetologia, 2006:49:2564-71

20. Aschner P, Katzeff $\mathrm{HL}$, Guo H, et al., Efficacy and safety of monotherapy of sitagliptin compared with metformin in patients with type 2 diabetes, Diabetes Obes Metab, 2010;12:252-61.

21. Goldstein BJ, Feinglos MN, Lunceford JK, et al., Effect of initial combination therapy with sitagliptin, a dipeptidyl peptidase-4 inhibitor, and metformin on glycemic control in patients with type 2 diabetes, Diabetes Care, 2007;30:1979-87.
22. Williams-Herman D, Johnson J, Teng R, et al., Efficacy and safety of sitagliptin and metformin as initial combination therapy and as monotherapy over 2 years in patients with type 2 diabetes, Diabetes Obes Metab, 2010;12:442-51.

23. Williams-Herman $D$, Johnson J, Teng R, et al., Efficacy and safety of initial combination therapy with sitagliptin and metformin in patients with type 2 diabetes: a 54-week study, Curr Med Res Opin, 2009;25:569-83.

24. Charbonnel B, Karasik A, Liu J, et al., Efficacy and safety of the dipeptidyl peptidase-4 inhibitor sitagliptin added to ongoing metformin therapy in patients with type 2 diabetes inadequately controlled with metformin alone, Diabetes Care, 2006;29:2638-43.

25. Nauck MA, Meininger G, Sheng D, et al., Efficacy and safety of the dipeptidyl peptidase- 4 inhibitor, sitagliptin, compared with the sulfonylurea, glipizide, in patients with type 2 diabetes inadequately controlled on metformin alone: a randomized, double-blind, non-inferiority trial, Diabetes Obes Metab, 2007;9:194-205

26. Seck T, Nauck M, Sheng D, et al., Safety and efficacy of treatment with sitagliptin or glipizide in patients with type 2 diabetes inadequately controlled on metformin: a 2-year study, Int J Clin Pract, 2010;64:562-76.

27. Arechavaleta R, Seck T, Chen Y, et al., Efficacy and safety of treatment with sitagliptin or glimepiride in patients with type 2 diabetes inadequately controlled on metformin monotherapy: a randomized, double-blind, non-inferiority trial, Diabetes obes Metab, 2011:13:160-8.

28. Scott R, Loeys T, Davies MJ, et al., Efficacy and safety of sitagliptin when added to ongoing metformin therapy in patients with type 2 diabetes, Diabetes Obes Metab, 2008;10:959-69.

29. Rosenstock J, Brazg R, Andryuk PJ, et al., Efficacy and safety of the dipeptidyl peptidase-4 inhibitor sitagliptin added to ongoing pioglitazone therapy in patients with type 2 diabetes: a 24-week, multicenter, randomized, double-blind, placebo-controlled, parallel-group study, Clin Ther, 
2006:28:1556-68.

30. Yoon KH, Shockey GR, Teng R, et al., Effect of initial combination therapy with sitagliptin, a dipeptidyl peptidase-4 inhibitor, and pioglitazone on glycemic control and measures of beta-cell function in patients with type 2 diabetes, Int I Clin Pract, 2011;65:154-64.

31. Hermansen K, Kipnes M, Luo E, et al., Efficacy and safety of the dipeptidyl peptidase-4 inhibitor, sitagliptin, in patients with type 2 diabetes mellitus inadequately controlled on glimepiride alone or on glimepiride and metformin, Diabetes Obes Metab, 2007:9:733-45.

32. Vilsboll T, Rosenstock J, Yki-Jarvinen $\mathrm{H}$, et al., Efficacy and safety of sitagliptin when added to insulin therapy in patients with type 2 diabetes, Diabetes Obes Metab, 2010:12:167-77.

33. Chacra AR, Tan GH, Ravichandran S, et al., Safety and efficacy of saxagliptin in combination with submaximal sulphonylurea versus up-titrated sulphonylurea over 76 weeks, Diab Vasc Dis Res, 2011;8:150-9.

34. DeFronzo RA, Hissa MN, Garber AJ, et al., The efficacy and safety of saxagliptin when added to metformin therapy in patients with inadequately controlled type 2 diabetes with metformin alone, Diabetes Care, 2009;32:1649-55.

35. Goke B, Gallwitz B, Eriksson J, et al., Saxagliptin is non-inferio to glipizide in patients with type 2 diabetes mellitus inadequately controlled on metformin alone: a 52-week randomised controlled trial, Int J Clin Pract, 2010;64:1619-31.

36. Hollander PL, Li J, Frederich R, et al., Safety and efficacy of saxagliptin added to thiazolidinedione over 76 weeks in patients with type 2 diabetes mellitus, Diab Vasc Dis Res 2011;8:125-35.

37. Jadzinsky M, Pfutzner A, Paz-Pacheco E, et al., Saxagliptin given in combination with metformin as initial therapy improves glycaemic control in patients with type 2 diabetes compared with either monotherapy: a randomized controlled trial, Diabetes Obes Metab, 2009;11:611-22.

38. Karyekar C, Donovan M, Allen E, et al., Efficacy and safety of saxagliptin combination therapy in US patients with type 2 diabetes, Postgrad Med, 2011;123:63-70.

39. Pfutzner A, Paz-Pacheco E, Allen E, et al., Initial combination therapy with saxagliptin and metformin provides sustained glycaemic control and is well tolerated for up to 76 weeks, Diabetes Obes Metab, 2011;13:567-76.

40. Rosenstock J, Aguilar-Salinas C, Klein E, et al., Effect of saxagliptin monotherapy in treatment-naive patients with type 2 diabetes, Curr Med Res Opin, 2009;25:2401-11.

41. Chacra AR, Tan GH, Apanovitch A, et al., Saxagliptin added to a submaximal dose of sulphonylurea improves glycaemic control compared with uptitration of sulphonylurea in patients with type 2 diabetes: a randomised controlled trial, Int I Clin Pract, 2009;63:1395-406.

42. Hollander P, Li J, Allen E, et al., Saxagliptin added to a thiazolidinedione improves glycemic control in patients with type 2 diabetes and inadequate control on thiazolidinedione alone, I Clin Endocrinol Metab, 2009;94:4810-9.

43. Del Prato $S$, Barnett $A H$, Huisman $H$, et al., Effect of linagliptin monotherapy on glycaemic control and markers of beta-cell function in patients with inadequately controlled type 2 diabetes: a randomized controlled trial, Diabetes Obes Metab, 2011:13:258-67.

44. Taskinen MR, Rosenstock J, Tamminen I, et al., Safety and efficacy of linagliptin as add-on therapy to metformin in patients with type 2 diabetes: a randomized, double-blind, placebo-controlled study, Diabetes Obes Metab, 2011;13:65-74.

45. Forst $\mathrm{T}$, Uhlig-Laske B, Ring A, et al., Linagliptin (BI 1356), a potent and selective DPP-4 inhibitor, is safe and efficacious in combination with metformin in patients with inadequately controlled Type 2 diabetes, Diabet Med, 2010;27:1409-19.

46. Gomis R, Espadero RM, Jones R, et al., Efficacy and safety of initial combination therapy with linagliptin and pioglitazone in patients with inadequately controlled type 2 diabetes: a randomized, double-blind, placebo-controlled study, Diabetes Obes Metab, 2011;13:653-61.

47. Owens DR, Swallow R, Dugi KA, Woerle HJ, Efficacy and safety of linagliptin in persons with Type 2 diabetes inadequately controlled by a combination of metformin and sulphonylurea: a 24-week randomized study, Diabet Med, 2011;28:1352-61.

48. Moretto TJ, Milton DR, Ridge TD, et al., Efficacy and tolerability of exenatide monotherapy over 24 weeks in antidiabetic drug-naive patients with type 2 diabetes: a randomized, double-blind, placebo-controlled, parallel-group study, Clin Ther, 2008;30:1448-60.

49. Buse JB, Henry RR, Han J, et al., Effects of exenatide (exendin-4) on glycemic control over 30 weeks in sulfonylurea-treated patients with type 2 diabetes, Diabetes Care, 2004;27:2628-35.

50. DeFronzo RA, Ratner RE, Han J, et al., Effects of exenatide (exendin-4) on glycemic control and weight over 30 weeks in metformin-treated patients with type 2 diabetes, Diabetes Care, 2005;28:1092-100.

51. Kendall DM, Riddle MC, Rosenstock J, et al., Effects of exenatide (exendin-4) on glycemic control over 30 weeks in patients with type 2 diabetes treated with metformin and a sulfonylurea, Diabetes Care, 2005;28:1083-91.

52. Zinman B, Hoogwerf BJ, Duran Garcia S, et al., The effect of adding exenatide to a thiazolidinedione in suboptimally controlled type 2 diabetes: a randomized trial, Ann Intern Med 2007;146:477-85

53. Buse JB, Rosenstock J, Sesti G, et al., Liraglutide once a day versus exenatide twice a day for type 2 diabetes: a 26-week randomised, parallel-group, multinational, open-label trial (LEAD-6), Lancet, 2009;374:39-47.

54. Buse JB, Sesti G, Schmidt WE, et al., Switching to once-daily liraglutide from twice-daily exenatide further improves glycemic control in patients with type 2 diabetes using oral agents, Diabetes Care, 2010:33:1300-3.

55. Garber A, Henry R, Ratner R, et al., Liraglutide versus glimepiride monotherapy for type 2 diabetes (LEAD-3 Mono) a randomised, 52-week, phase III, double-blind, paralleltreatment trial, Lancet, 2009;373:473-81.

56. Garber A, Henry RR, Ratner R, et al., Liraglutide, a once-daily human glucagon-like peptide 1 analogue, provides sustained improvements in glycaemic control and weight for 2 years as monotherapy compared with glimepiride in patients with type 2 diabetes, Diabetes Obes Metab, 2011;13:348-56.

57. Marre M, Shaw J, Brandle M, et al., Liraglutide, a once-daily human GLP-1 analogue, added to a sulphonylurea over 26 weeks produces greater improvements in glycaemic and weight control compared with adding rosiglitazone or placebo in subjects with Type 2 diabetes (LEAD-1 SU), Diabet Med, 2009;26:268-78.

58. Nauck M, Frid A, Hermansen K, et al., Efficacy and safety comparison of liraglutide, glimepiride, and placebo, all in combination with metformin, in type 2 diabetes: the LEAD (liraglutide effect and action in diabetes)-2 study, Diabetes Care, 2009:32:84-90

59. Russell-Jones $\mathrm{D}$, Vaag $\mathrm{A}$, Schmitz $\mathrm{O}$, et al., Liraglutide vs insulin glargine and placebo in combination with metformin and sulfonylurea therapy in type 2 diabetes mellitus (LEAD- 5 met+SU): a randomised controlled trial, Diabetologia, 2009;52:2046-55.

60. Zinman B, Gerich J, Buse JB, et al., Efficacy and safety of the human glucagon-like peptide-1 analog liraglutide in combination with metformin and thiazolidinedione in patients with type 2 diabetes (LEAD-4 Met+TZD), Diabetes Care, 2009;32:1224-30

61. Nauck MA, Vilsboll T, Gallwitz B, et al., Incretin-based therapies: viewpoints on the way to consensus, Diabetes Care, 2009:32(Suppl. 2):S223-31.

62. Davies M, Pratley R, Hammer M, et al., Liraglutide improves treatment satisfaction in people with Type 2 diabetes compared with sitagliptin, each as an add on to metformin, Diabet Med, 2011;28:333-7.

63. Davies MJ, Chubb BD, Smith IC, et al., Cost-utility analysis of liraglutide compared with sulphonylurea or sitagliptin, all as add-on to metformin monotherapy in Type 2 diabetes mellitus, Diabet Med, 2011; epub ahead of print

64. DeFronzo RA, Okerson T, Viswanathan P, et al., Effects of exenatide versus sitagliptin on postprandial glucose, insulin and glucagon secretion, gastric emptying, and caloric intake: a randomized, cross-over study, Curr Med Res Opin, 2008;24:2943-52.

65. Berg JK, Shenouda SK, Heilmann CR, et al., Effects of exenatide twice daily versus sitagliptin on $24-\mathrm{h}$ glucose glucoregulatory and hormonal measures: a randomized double-blind, crossover study, Diabetes Obes Metab, 2011;13:982-9.

66. Pratley RE, Nauck M, Bailey T, et al., Liraglutide versus sitagliptin for patients with type 2 diabetes who did not have adequate glycaemic control with metformin: a 26-week, randomised, parallel-group, open-label trial, Lancet, 2010;375:1447-56

67. Buse B, Nauck MA, Forst T, et al., Efficacy and safety of exenatide once weekly versus liraglutide in subjects with type 2 diabetes (DURATION-6): a randomised, open-label study, Abstract 75, Diabetologia, 2011;54:S38.

68. Drucker DJ, Sherman SI, Bergenstal RM, et al., The safety of incretin-based therapies-review of the scientific evidence, I Clin Endocrinol Metab, 2011;96:2027-31.

69. Garg R, Chen W, Pendergrass M, Acute pancreatitis in type 2 diabetes treated with exenatide or sitagliptin: a retrospective observational pharmacy claims analysis, Diabetes Care, 2010;33:2349-54

70. Parks M, Rosebraugh $\mathrm{C}$, Weighing risks and benefits of liraglutide-the FDA's review of a new antidiabetic therapy, N Engl I Med, 2010;362:774-7.

71. Bjerre Knudsen L, Madsen LW, Andersen S, et al., Glucagon-like Peptide-1 receptor agonists activate rodent thyroid C-cells causing calcitonin release and C-cell proliferation, Endocrinology, 2010;151:1473-86

72. Vilsboll T, Zdravkovic M, Le-Thi T, et al., Liraglutide, a long acting human glucagon-like peptide- 1 analog, given as monotherapy significantly improves glycemic control and lowers body weight without risk of hypoglycemia in patients with type 2 diabetes, Diabetes Care, 2007;30:1608-10.

73. Pannacciulli N, Le DS, Salbe AD, et al., Postprandial glucagonlike peptide-1 (GLP-1) response is positively associated with changes in neuronal activity of brain areas implicated in satiety and food intake regulation in humans, Neuroimage, 2007:35:511-7.

74. Best JH, Rubin RR, Peyrot M, et al., Weight-related quality of life, health utility, psychological well-being, and satisfaction with exenatide once weekly compared with sitagliptin or pioglitazone after 26 weeks of treatment, Diabetes Care, 2011;34:314-9.

75. Corsonello A, Pedone C, Corica F, et al., Concealed renal failure and adverse drug reactions in older patients with type 2 diabetes mellitus, J Gerontol A Biol Sci Med Sci, 2005;60:1147-51.

76. Koro CE, Lee BH, Bowlin SJ, Antidiabetic medication use and prevalence of chronic kidney disease among patients with type 2 diabetes mellitus in the United States, Clin Ther, 2009;31:2608-17.

77. Davidson JA, Brett J, Falahati A, et al., Mild renal impairment and the efficacy and safety of liraglutide, Endocr Pract, 2011;17:345-55

78. Polster M, Zanutto E, MCDonald S, et al., A comparison of preferences for two GLP-1 products-liraglutide and exenatide-for the treatment of type 2 diabetes, I Med Econ, 2010;13:655-61

79. Zinman B, Schmidt WE, Moses A, et al., Achieving a clinically relevant composite outcome of an $\mathrm{HDA}(1 \mathrm{C})$ of $<7 \%$ without weight gain or hypoglycaemia in type 2 diabetes: a metaanalysis of the liraglutide clinical trial programme, Diabetes obes Metab, 2012;14:77-82

80. Kielgast U, Krarup T, Holst JJ, et al., Four weeks of treatment with liraglutide reduces insulin dose without loss of glycemic control in type 1 diabetic patients with and without residual beta-cell function, Diabetes Care, 2011;34:1463-8.

81. Raman VS, Mason KJ, Rodriguez LM, et al., The role of adjunctive exenatide therapy in pediatric type 1 diabetes, Diabetes Care, 2010;33:1294-6.

82. Varanasi A, Bellini N, Rawal D, et al., Liraglutide as additional treatment for type 1 diabetes, Eur J Endocrinol, 2011:165:77-84.

83. DeFronzo RA, Banting Lecture. From the triumvirate to the ominous octet: a new paradigm for the treatment of type 2 diabetes mellitus, Diabetes, 2009;58:773-95.

84. Forst $\mathrm{T}$, Uhlig-Laske $\mathrm{B}$, Ring $\mathrm{A}$, et al., The oral DPP-4 inhibitor linagliptin significantly lowers $\mathrm{HbA} 1 \mathrm{C}$ after 4 weeks of treatment in patients with type 2 diabetes mellitus, Diabetes Obes Metab, 2011:13:542-50.

85. Pratley R, Nauck M, Bailey T, et al., One year of liraglutide treatment offers sustained and more effective glycaemic control and weight reduction compared with sitagliptin, both in combination with metformin, in patients with type 2 diabetes: a randomised, parallel-group, open-label trial, Int I Clin Pract, 2011;65:397-407. 